\title{
Ölünceye Kadar Bakma Sözleşmesi Kapsamında Bakım Alacaklısının Saklı Payı İhlal Kastı ile Yaptığı Sağlararası Kazandırmaların Tenkisi
}

\author{
Şeyda Dursun Karaahmetoğlu* (i)
}

\section{Öz}

Ölünceye kadar bakma sözleşmesi ivazlı bir sözleşmedir. Bu bakımdan ölünceye kadar bakma sözleşmesi uyarınca bakım borçlusuna yapılmış olan devirlerin Türk Medeni Kanunu'nun (MK) 565. maddesi uyarınca terekeye eklenerek tenkisi mümkün değildir. Zira sağlararası bir kazandırmanın MK m. 565 gereğince tenkis edilebilmesi için karşılıksız bir kazandırma olması gerekmektedir. Ancak ölünceye kadar bakma sözleşmesi kimi durumlarda bağışlama sözleşmesi ile bir arada bulunabilir ve karma bağışlama niteliğini haiz olabilir. Bu durumda sözleşmenin karşılıksız olan kısmı tenkise tabi olacaktır. Ölünceye kadar bakma sözleşmesinin tenkisi bakımından uygulamada en çok karşımıza çıkan husus bakım alacaklısının bu sözleşme kapsamında saklı payı ihlal kastı ile gerçekleştirmiş olduğu devirlerdir. Saklı payı ihlal kastının varlığından bahsedilebilmesi için bakım alacaklısının sağlararası kazandırmayı yaparken saklı paylı mirasçılarının haklarını ihlal edebileceğini bilmesine rağmen söz konusu kazandırmayı yapması gerekmektedir. Yargıtay tarafindan verilmiş olan kararlarda bakım alacaklısının ölünceye kadar bakma sözleşmesini kurarken özel bakım ihtiyacı içerisinde olmaması, bakım alacaklısı ile bakım borçlusunun edimleri arasında dengesizlik bulunması ya da bakım alacaklısının malvarlığının büyük bir kısmı veya tamamını bakım borçlusuna devretmesi hallerinde çoğunlukla bakım alacaklısının saklı payı ihlal kastının varlığından bahsedilmektedir. Oysaki söz konusu hususların varlığı tek başına doğrudan bakım alacaklısının saklı payı ihlal kast ile hareket ettiğini göstermez. Bakım alacaklısının saklı payı ihlal kastından bahsedilebilmesi için söz konusu kriterler başkaca delillerle de desteklenmelidir. Bakım alacaklısı, saklı payı ihlal kastı ile hareket ettiği kimi durumlarda gerçekleştirmiş olduğu devrin tenkisini engellemek için muvazaalı işlemlere başvurabilir. Bu durumda bakım alacaklısının saklı payı ihlal kastının yanı sıra ölünceye kadar bakma sözleşmesinin altında gizlenmiş olan bir bağışlama sözleşmesinin varlığı ve tarafların muvazaa anlaşması kanıtlanarak söz konusu sözleşmeye bağlı olarak gerçekleştirilmiş olan devrin geçersizliğinin talep edilmesi mümkündür.

\section{Anahtar Kelimeler}

Ölünceye Kadar Bakma Sözleşmesi, Sağlararası Kazandırma, Saklı Payı Ihlal Kastı, Tenkis, Muvazaa

The Abatement of Inter Vivos Transfers Made by a Beneficiary with the Intent to Violate the Compulsory Portion (The Statutory Entitlement) within the Scope of a Lifetime Maintenance Agreement

\begin{abstract}
A lifetime maintenance agreement is a reciprocal agreement. Therefore, the transfer of an estate or individual assets to a settlor made by a beneficiary is not subject to abatement and cannot be added to a decedent's assets according to Article 565 of the Turkish Civil Code. However, sometimes, a lifetime maintenance agreement can accompany a donation agreement. The resulting agreement can then be defined as a mixed gift. In this context, only the gratuitous part of the agreement would be subject to abatement. The majority of cases related to abatement of the lifetime maintenance agreement relate to the alienation made by the beneficiary with the obvious intent of circumventing
\end{abstract}

* Sorumlu Yazar: Şeyda Dursun Karaahmetoğlu (Arş. Gör. Dr.), Yalova Üniversitesi, Hukuk Fakültesi, Medeni Hukuk Anabilim Dalı, Yalova, Türkiye. E-posta: seyda.dursun@yalova.edu.tr. ORCID: 0000-0001-6490-1324

Atıf: Dursun Karaahmetoglu S, "Ölünceye Kadar Bakma Sözleşmesi Kapsamında Bakım Alacaklısının Saklı Payı İhlal Kastı ile Yaptığı Sağlararası Kazandırmaların Tenkisi" (2021) 79(4) İstanbul Hukuk Mecmuası 1231. https://doi.org/10.26650/mecmua.2021.79.4.0004 
the existing limitations on his or her testamentary freedom. There is an obvious intent of the beneficiary to violate the compulsory portion (the statutory entitlement) when he transfers an estate or individual assets when he is aware of the violation of the requirements for a compulsory portion for heirs with such a transfer. According to the Turkish Court of Cassation, for instance, the beneficiary intends to violate the compulsory portion (the statutory entitlement) if he is not in need of special care at the beginning of the contract period. Additionally, according to the Turkish Court of Cassation, the beneficiary also obviously intends to violate the compulsory portion (the statutory entitlement) if the beneficiary transfers all or most of his assets to the settlor. If there is an imbalance between the obligations of the beneficiary and the settlor, the Turkish Court of Cassation considers the beneficiary's intent to violate the compulsory portion (the statutory entitlement). However, no single criterion, among those which have been found by the Turkish Court of Cassation to show intent, is sufficient in and of itself to show the intent of the beneficiary to violate the compulsory portion (the statutory entitlement). In order to determine the intent of the beneficiary to violate the compulsory portion (the statutory entitlement), the criteria found by the Turkish Court of Cassation must be supported by additional evidence. In order to avoid abatement, the beneficiary may transfer his estate or individual assets with a fictitious transaction. In this context, the party challenging the donation must prove that the donation agreement, hidden behind the lifetime maintenance agreement, represents the agreement of the parties to a fictitious transaction in addition to demonstrating the beneficiary's intent to violate the compulsory portion (the statutory entitlement).

\section{Keywords}

Lifetime Maintenance Agreement, Inter Vivos Transfer, The Intention of The Beneficiary to Violate Compulsory Portion (The Statutory Entitlement), Abatement, Fictitious Contract

\section{Extended Summary}

According to Article 611 of Turkish Code of Obligations (TCO) Number 6098, a lifetime maintenance agreement is a contract through which the beneficiary undertakes to transfer an estate or individual assets to the settlor in return for an undertaking to provide maintenance and care for the beneficiary's lifetime. In this context, the primary obligation of the settlor is to provide the beneficiary with maintenance and care for life. On the other hand, the main obligation of the beneficiary is to transfer an estate or individual assets to the settlor.

According to Article 565 of Turkish Civil Code (TCC) Number 4721, inter vivos gifts are added to the deceased's estate and are subject to abatement. A lifetime maintenance agreement, on the other hand, is a reciprocal agreement; therefore, the transfer of an estate or individual assets to the settlor made by the beneficiary is not subject to abatement and cannot be added to the deceased's assets. However, sometimes, the lifetime maintenance agreement can be accompanied by a donation agreement. The resulting agreement can then be defined as a mixed gift. In this context, the gratuitous portion of the gifts provided under the agreement is subject to abatement.

The majority of cases related to abatement of a lifetime maintenance agreement relate to the alienation made by the beneficiary with the obvious intent to circumvent the limitations on his or her testamentary freedom. An obvious intent of the beneficiary to violate the compulsory portion (the statutory entitlement) can be found when the beneficiary transfers an estate or individual assets when he is aware of the violation 
of the compulsory portion of certain heirs by virtue of this transfer. However, there is no obvious intent if the beneficiary has no heirs entitled to the compulsory portion (the statutory entitlement) at the time of the transfer.

The Turkish Court of Cassation has set forth some criteria regarding the intent to violate the compulsory portion in the context of the lifetime maintenance agreement. According to the Court, for instance, the beneficiary will be found to have an intent to violate the compulsory portion (the statutory entitlement) if the beneficiary is not in need of special care at the inception of the contract period. In addition to the established criteria, according to the Court of Cassation, the beneficiary shows an intent to violate the compulsory portion (the statutory entitlement) if the beneficiary transfers all or most of his assets to the settlor. If there is an imbalance between the obligation of the beneficiary and those of the settlor, the Turkish Court of Cassation considers the intent of the beneficiary to violate the compulsory portion (the statutory entitlement). However, no one of the established criteria is deemed solely sufficient to show the beneficiary's intent to violate the compulsory portion (the statutory entitlement). In order to establish the intent of the beneficiary to violate the compulsory portion (the statutory entitlement), the criteria found by Turkish Court of Cassation must be supported by additional evidence.

As mentioned previously, according to TCO Article 565, the alienations made by the beneficiary with the obvious intent to circumvent the limitations on his or her testamentary freedom are subject to abatement. In order to avoid abatement, the beneficiary may transfer his estate or individual assets with a fictitious transaction. In such a case, the transfer of the estate and individual assets made within the context of a lifetime maintenance agreement is not valid. Any one of the heirs entitled to the compulsory portion can claim against the fictitious contract. In this context, the heir making the claim must prove that the donation agreement, hidden behind the lifetime maintenance agreement, represents the agreement of the parties regarding a fictitious transaction in addition to proving the intent of the beneficiary to violate the compulsory portion (the statutory entitlement). 


\section{Giriş}

Ölünceye kadar bakma sözleşmesi Türk Borçlar Kanunu'nun (BK) 611. maddesinde tanımlanmıştır. Anılan düzenlemeye göre, ölünceye kadar bakma sözleşmesi bakım borçlusunun bakım alacaklısını ölünceye kadar bakıp onu gözetme, bakım alacaklısının da bunun karşıllı̆ında malvarlığı değerlerini ona devretme borcu altına girmiş olduğu sözleşmedir.

BK m 611 uyarınca, ölünceye kadar bakma sözleşmesi kapsamında bakım borçlusunun yerine getirmesi gereken temel yükümlülüğü bakım alacaklısını ölünceye kadar bakıp onu gözetmektir. Ölünceye kadar bakıp gözetme borcu gereğince, bakım borçlusu, bakım alacaklısına uygun gıda ve konut ${ }^{1}$ sağlamalıdır (BK m 614/II). Bundan başka bakım borçlusu bakım alacaklısının hastalığında onun bakım ve tedavisini sağlamakla yükümlüdür (BK m 614/II). Bakım borçlusunun bakma ve gözetme yükümlülüğü karşıllğında bakım alacaklısı da bir malvarlığını ya da bazı malvarlığı değerlerini bakım borçlusuna devretmekle yükümlüdür.

Bakım alacaklısının üstlenmiş olduğu söz konusu malvarlı̆̆ değerini devretme borcunu hayattayken yerine getirmeyi taahhüt ettiği durumda bakım alacaklısı ve bakım borçlusu arasında borçlar hukukuna tabi bir ölünceye kadar bakma sözleşmesi mevcuttur $^{2}$. Bu türdeki bir ölünceye kadar bakma sözleşmesinin yapılmasıyla birlikte bakım borçlusu malvarlığı değerinin kendisine devri bakımından kişisel nitelikte bir hakka sahip olur ${ }^{3}$ ve söz konusu hakkına istinaden bakım alacaklısından sözleşme konusu malvarlığ 1 değerinin kendisine devrini talep edebilir. Bakım borçlusu ise söz konusu borcunu ifa edebilmesi için malvarlığı değerinin türüne göre tasarruf işlemini gerçekleştirecektir.

BK m 611/II’ye göre, ölünceye kadar bakma sözleşmesi kapsamında bakım alacaklısı bakım borçlusunu mirasçı atamışsa bu sözleşmeye miras sözleşmesine

BK m 614/I’e göre, ölünceye kadar bakma sözleşmesinin kurulması ile birlikte bakım alacaklısı bakım borçlusunun aile topluluğuna katılmış olur. Ancak taraflar sözleşmede aksini kararlaştırabilirler. Tarafların anlaşmaları neticesinde bakım borçlusunun bakma ve bakım alacaklısını gözetleme borcu bakım alacaklısının evinde de ifa edebilir. Bu yönde bkz.: Turan Şahin, Ölünceye Kadar Bakma Sözleșmesi (Seçkin 2019) 126-127. Tarafların anlașması halinde bakım alacaklısına ayrı bir konut açılarak orada bakılacağı hususunda bkz.: Aydın Zevkliler ve K. Emre Gökyayla, Borçlar Hukuku Özel Borç İlişkileri (20. Basl, Vedat 2020) 779; Alpaslan Akartepe, Ölünceye Kadar Bakma Sözleşmesi, (Vedat 2010) 119; Lütfü Dalamanl,, Tatbikatta Satı̧ Vaadleri Ölünceye Kadar Bakma ve Miras Taksim Sözleşmeleri (Kazancı 1980)137.

Bakım alacaklısının kusurlu tutum ve davranışının bakma yükümlüsü için birlikte oturmayı tahammül edilemez hale getirmesinden dolayı bakım borçlusunun ayrı evde oturarak bakıp gözetme görevini yerine getirmiş olmasının sözleşmeye aykırılık oluşturmayacağı konusunda bkz.: Yargıtay 2 HD, 1973-8154/180, 15.01.1974 (Kazancı Hukuk-Çevrimiçi 03.01.2021)

Bakım alacaklısının yaşadığı süre boyunca sözleşme ile bağlanmak istemeyip bakım borçlusunun yanından ayrılma, başka bir yerde ikamet edip geçimini sağlama yetkisini haiz olduğu hallerde taraflar arasındaki sözleşmenin ölünceye kadar bakma sözleşmesi olarak nitelendirilemeyeceği yönünde bkz.: Senai Olgaç, Ömür Boyunca Gelir Ölünceye Kadar Bakma Akdi (Olgaç 1978) 21.

Kenan Tunçomağ, Ölünceye Kadar Bakma Akdi (Ayyıldız 1959) 25-26; Erhan Günay, Ölünceye Kadar Baklp Gözetme Sözleşmesinden Kaynaklanan Uyuşmazlıklar (3. Bask1, Seçkin 2020) 22-23; Şahin (n 1) 30; Akartepe (n 1) 25-27.

3 Günay (n 2) 23-24; Marc Schaetzle, Berner Kommentar, Das Obligationenrecht, 2. Abteilung Die einzelnen Vertragsverhceltnisse, 7. Teilband (Zweite Auflage, Verlag Stampfli 1978) Artikel 521 N. 5. Aynı yönde bkz.: Şahin (n 1) 113. 
ilişkin hükümler uygulanacaktır. Başka bir ifade ile miras hukukuna tabi olan ölünceye kadar bakma sözleşmesinde, bakım alacaklısı hayattayken bakım borçlusuna herhangi bir malvarlığı değeri devretmemekte, onun yerine bakım borçlusunu mirasçı atamaktadır ${ }^{4}$. Dolayısıyla, miras hukukuna tabi bir ölünceye kadar bakma sözleşmesinde bakım alacaklısı borcunu bakım borçlusunu mirasçı atamak suretiyle ifa etmektedir 5 . Her ne kadar BK m 611/II'de yalnızca mirasç1 atama ifadesi kullanılmış olsa da doktrinde hakim görüş, isabetli olarak, bu ifadenin geniş yorumlanması gerektiğini ve dolayısıyla bakım alacaklısının bakım borçlusu lehine bir vasiyet gerçekleştirdiği durumda bile taraflar arasında miras hukukuna tabi bir ölünceye kadar bakma sözleşmesi söz konusu olduğunu savunmaktadır ${ }^{6}$.

Ölünceye kadar bakma sözleşmesi kapsamında bakım alacaklısının gerçekleştirmiş olduğu malvarlığı devri veya ölüme bağlı tasarruf neticesinde saklı paylı mirasçıların saklı payları zedelenmiş olabilir. Bu durumda bakım alacaklısının ölümünün ardından saklı payları zedelenen mirasçılar tenkis davası açabilirler. Nitekim BK m 615/III'te de mirasçıların tenkis davası açma hakkının saklı olduğu belirtilmiştir. Özellikle borçlar hukukuna tabi ölünceye kadar bakma sözleşmesi uyarınca sağlarararası bir işlemle bakım borçlusuna devredilmiş malvarlığı değerlerinin tenkisi bakımından uygulamada birtakım sorunlar mevcuttur. Şöyle ki bakım alacaklısının saklı payı ihlal kastı ile yapmış olduğu kazandırmaların terekeye iadesi bakımından açılan davalarda saklı payı ihlal kastının değerlendirilmesi, açılması gereken davanın tenkis davası $\mathrm{m} 1$ yoksa muvazaa sebebiyle tapu iptal davası $\mathrm{m} 1$ olduğu hususunda farklı uygulamalar söz konusudur. Anılan duruma istinaden bu çalışmada ölünceye kadar bakma sözleşmesi kapsamında bakım borçlusunun saklı payı ihlal kastı ile yaptığı sağlararası kazandırmaların tenkisi ele alınacaktır. İlk olarak ölünceye kadar bakma sözleşmesi bakımından tenkis davası açılabilmesinin şartları genel olarak incelenecektir. Sonrasında bakım alacaklısının saklı payı ihlal kastı ile yapmış olduğu kazandırmaların ortak özellikleri incelenecektir. Ardından Yargıtay kararları da dikkate alınarak bakım alacaklısının sağlararası kazandırmaları bakımından saklı payı ihlal kastının mevcut olabileceği haller tartışlacaktır. Son olarak ise söz konusu kazandırmalar muvazaa açısından ele alınacaktır.

\footnotetext{
Günay (n 2) 20.

Tunçomağ (n 2) 25,42; Şahin (n 1) 31; Şebnem Akipek Öcal, “Ölünceye Kadar Bakma Sözleşmesi”, 2018) 6(1) Kadir Has Üniversitesi Hukuk Fakültesi Dergisi 83, 86. Aynı yönde bkz.: Yasemin Durak, “Ölünceye Kadar Bakma Sözleşmesi”, 2015 1(1) Başkent Üniversitesi Hukuku Fakültesi Dergisi 265, 286.

6 Şahin (n 1) 31,117; Olgaç (n 1) 23; Tunçomağ (n 2) 29; Ebül'ula Mardin, Ölünceye Kadar Bakma Mukavelesi, Hukuk Fakültesi Mecmuasından Ayrı Bası, Kenan 1940) 64; Fikret Arık, "Ölünceye Kadar Bakma Akdi” (1959) 3 Adliye Dergisi 277, 285; Durak (n 5) 270; Akartepe (n 1) 29; Krauskopf Frédéric, Präjudizienbuch OR Die Rechtsprechung des Bundesgerichts (1875-2015), Herausgeber: Peter Gauch,Viktor Aepli ve Hubert Stöckli (Neunte Auflage, Schulthess, 2016) Art. 521 N. 2; Thomas Bauer, Basler Kommentar Obligationenrecht I Art. 1-529, Herausgeber: Heinrich Honsell, Nedim Peter Vogt ve Wolfgang Wiegand, (6. Auflage, Helbing Lichtenhahn 2015) Art. 521 N. 7; Schaetzle (n 3)Art. 521 N. 38; Eugen Bucher, Schweizerisches Obligationenrecht Besonderer Teil (3. Auflage, Schulthess 1988) 317; Semih Akkök, Türk Hukuku'nda Miras Bırakanın Muvazaalı İşlemleri ve Buna Bağlanan Hukuki Sonuçlar (On İki Levha, 2020) 104105. Aynı yönde bkz.: Esra Eviz, Muris Muvazaası (On İki Levha, 2019), 94. Miras hukukuna tabi bir ölünceye kadar bakma sözleşmesinin yalnızca mirasçı ataması halinde mümkün olduğu yönünde bkz.: Fikret Eren, Borçlar Hukuku Özel Hükümler (8. Bask1, Yetkin 2020) N. 2807, 2816, 2825; Zevkliler ve Gökyayla (n 1) 774; Akipek Öcal (n 5) 86.
} 


\section{Bakım Alacaklısının Yaptığı Sağlararası Kazandırmaların Tenkisinin Şartları}

\section{A. Sakıı Paylı Mirasçıların Sakıı Paylarının İhlal Edilmiş Olması}

Hukukumuzda her birey yasal düzenin kendisine izin verdiği sınırlar içerisinde malvarlığı üzerinde dilediği gibi sağlararası bir işlemle tasarrufta bulunabilir ya da ölüme bağlı tasarrufta bulunarak malvarlığını oluşturan değerlerin ölümünden sonra kime ait olacağını belirleyebilir ${ }^{7}$. Nitekim MK m. 514/I'de de mirasbırakanın tasarruf özgürlüğünün sınırları içerisinde malvarlığının tamamı ya da bir kısmında ölüme bağlı tasarrufta bulunabileceği belirtilmiştir.

MK m. 514/II gereğince, mirasbırakanın terekesi üzerinde tasarrufta bulunmadı̆̆ 1 kısım yasal mirasçılarına kalacaktır. Dolayısıyla mirasbırakanın yapmış olduğu ölüme bağlı tasarrufların geçerli olması halinde yasal mirasçıların miras payları kısmen ya da tamamen ortadan kalkacaktır'. Ancak MK m. 506' da belirtilmiş olan saklı paylı mirasçılar saklı paylarının ihlal edilmesi durumunda tenkis davası açarak mirasbırakanın yapmış olduğu ölüme bağlı tasarrufların saklı paylarını ihlal etmeyecek bir sınıra düşürülmesini talep edebilirler. Diğer yandan, yalnızca mirasbırakanca yapılmış olan ölüme bağlı tasarruflar değil MK m. 565’te belirtilenlerle sınırlı olmak üzere mirasbırakanın ölmeden önce yapmış olduğu karşılıksız kazandırmalar da tenkise tabi olacaktır.

Yukarıda ifade edilmiş olduğu üzere tenkis davası ancak mirasbırakanın gerçekleştirmiş olduğu tasarrufların serbest tasarruf oranını aşarak saklı paylı mirasçıların paylarını ihlal etmesi halinde gündeme gelecektir. Dolayısıyla bakım alacaklısının yapmış olduğu ölüme bağlı tasarruflar ve MK m. 565'te sınırlı sayıda belirtilmiş olan sağlararası kazandırmalar neticesinde serbest tasarruf oranı aşılarak saklı paylı mirasçıların saklı paylarının ihlal edilmesi halinde tenkis davası açılabilir. Çalışmamızda yalnızca borçlar hukukuna tabi ölünceye kadar bakma sözleşmesinin ifası sebebiyle yapılan sağlararası kazandırmaların tenkisi ele alınacağı için bakım alacaklısının yapmış olduğu tasarrufların serbest tasarruf oranını aşarak saklı paylı mirasçıların saklı paylarını ihlal etmesi halinde söz konusu kazandırmanın tenkisi mümkün olacaktır.

Bakım alacaklısının terekesi ile saklı paylı mirasçılarının saklı payları toplamı arasındaki fark serbest tasarruf oranını ifade etmektedir. Tasarruf oranının belirlenebilmesi için bakım alacaklısının bakım borçlusu lehine yapmış olduğu sağlararası bir kazandırmanın tenkise tabi olup olmadığının belirlenebilmesi

\footnotetext{
Rona Serozan ve Baki İlkay Engin, Miras Hukuku (6. Baskı, Seçkin, 2019) § 3 N. 1-2. Aynı yönde bkz.: Stephan Wolf, "Verfügungen unter Lebenden vs. «unzulässige» Umgehung der Verfügungsbeschränkung - wann greift die Herabsetzungsklage gemäss Art. 527 Ziff. 4 ZGB? 2014 (150) Zeitschrift des bernischen Juristenvereins 435, 437.

Serozan ve Engin (n 7) § 3 N. 1-2.
} 
için terekenin parasal değeri hesaplanmalıdır. Terekenin parasal değerinin hesaplanabilmesi için öncelikle bakım alacaklısının aktifleri onun öldüğü gün dikkate alınarak belirlenmelidir (MK m. 507). Terekenin aktifindeki değerler tespit edildikten sonra belirlenmiş olan bu değerden MK m. 507/II'de belirtilmiş olan değerlerin çıkartılması gerekir ${ }^{9}$ ve böylelikle net tereke tespit edilir. Tespit edilen net terekeye bakım alacaklısının sağlararası ivazsız kazandırmalarından denkleştirmeye tabi olanlar (MK m. 669), bakım alacaklısının sağlararası ivazsız kazandırmalarından tenkise tabi olanlar (MK m. 508-565) ve hayat sigortası alım bedeli (MK m. 567) eklenir. Ortaya çıkan tereke değeri üzerinden serbest tasarruf oranı dikkate alınarak yapılan hesaplama neticesinde bakım alacaklısının saklı paylı mirasçılarının saklı paylarının ihlal edildiği sonucuna varılırsa $\mathrm{MK}$ m. 570'teki sıra izlenerek önce ölüme bağlı tasarruflar sonra ise sağlararası kazandırmalar tenkis edilir.

\section{B. Sağlararası Kazandırmaların İvazsız Nitelikte Olması}

MK m. 560 uyarınca saklı paylarını tam olarak elde edemeyen mirasçılar, mirasbırakanın serbest tasarruf oranını aşan tasarruflarının tenkisini dava edebilir. Söz konusu hükümde her ne kadar yalnızca mirasbırakanın ölüme bağlı tasarruflarından bahsedilmiş olsa da MK m. 565 ve 570 hükümleri dikkate alındığında mirasbırakanın ölmeden önce yapmış olduğu sağlararası kazandırmalardan da bazılarının tenkise tabi tutulacağı sonucuna varılacaktır.

MK m. 565'e göre, denkleştirmeye tabi olmaktan kurtulan kazandırmalar, mirasbırakanın mirastan feragat karşıllğı ödemiş olduğu ivaz, serbestçe dönme hakkının saklı tutulduğu bağışlamalar ve-adet üzerine verilenler hariç-mirasbırakanın ölmeden önce son bir yıl içinde yapmış olduğu bağışlamalar ve mirasbırakanın saklı pay1 etkisiz kılma amacıyla yapmış olduğu kazandırmalar da ölüme bağlı tasarruflar gibi tenkise tabi olacaktır. Anılan hükümde sınırlı sayıda belirtilmiş olan söz konusu kazandırmaların ortak özelliği ivazsız olmalarıdır ${ }^{10}$. Zaten bir ivaz karşılığı yapılmış olan sağlararası kazandırmalarda, kazandırmada bulunan kimsenin edimi karşıllı̆ında malvarlığına başka bir malvarlığı değeri girmiş olduğu için mirasbırakanın ölmeden önce yapmış olduğu ivazlı kazandırmalar tenkise tabi olmayacaktır. Dolayısıyla bu hususlar dikkate alındığında, ölünceye kadar bakma sözleşmesi kapsamında bakım

\footnotetext{
MK m. 507/II gereğince, tasarruf edilebilir kısım hesaplanırken mirasbırakanın borçları, cenaze giderleri, terekenin mühürlenmesi ve yazım giderleri, mirasbırakanla birlikte yaşayan ve onun tarafından bakılan kimselerin üç aylık geçim giderleri terekeden indirilir.

Ayrıca bkz.: Fikret Eren ve İpek Yücer Aktürk, Türk Miras Hukuku (3. Baskı, Yetkin 2020) N. 745. Yazarlar MK m. 507/II'de sayılmamasına rağmen terekenin pasif kısmında ayrıca mirasbırakanın ölümünde henüz eğitim ve öğrenimini tamamlamamış olan veya sakat çocuklara paylaşmada hakkaniyete uygun olarak yapılacak ödemelerin ve MK m. 641/II kapsamında ana ve baba veya büyük ana ve büyük baba ile birlikte yaşayan ve emeklerini ve gelirlerini aileye özgüleyen ergin çocuklar ile torunlara verilecek tazminatın da yer alacağını belirtmişlerdir.

10 Necip Kocayusufpaşaoğlu, Miras Hukuku (3. Bası, Filiz 1987) 381; Zahit İmre ve Hasan Erman, Miras Hukuku (15. Basım, Der 2021) 268; Sezer Çabri, Miras Hukuku Şerhi (TMK m. 495-574) Cilt-I (On İki Levha, 2018) N. 1493; Bilge Öztan, Miras Hukuku (11. Bası, Yetkin 2020) 97; Cem Akbıyı, Karma Bağışlama Kavramı ve Miras Hukukundaki Yeri (Alfa 1997) 74; Ahmet Nar, Türk Miras Hukukunda Tenkis, (On İki Levha 2016) 143-144.
} 
alacaklısının bakım borçlusuna olan borcunu ifa etmek amacıyla yapmış olduğu sağlararası kazandırmaların tenkis edilebilmesi için anılan düzenlemelerden birinin kapsamında yer alarak kısmen veya tamamen ivazsızlık şartını sağlaması gerektiği sonucuna varılabilir.

Ölünceye kadar bakma sözleşmesinin tarafları arasında borçlar hukukuna tabi olan bir sözleşme olduğu ihtimalde bakım alacaklısı, bakım borçlusuna bir ya da birden fazla malvarlığı değerini devretme borcu altına girmektedir. Bu sözleşme ile üstlenmiş olduğu devir borcu taşınmazlarda tapuya tescille, taşınırlarda zilyetliğin devri ile alacaklar bakımından ise alacağın devri ile gerçekleştirilir. İster borçlar hukukuna tabi isterse de miras hukukuna tabi bir ölünceye kadar bakma sözleşmesi olsun bakım alacaklısı söz konusu edimleri bakım borçlusunun kendisine ölünceye kadar bakma ve onu gözetme borcu karşıllğında yerine getirmektedir. Başka bir ifade ile hem bakım alacaklısı hem de bakım borçlusu edimlerini ivaz elde etme düşüncesi ile yerine getirmektedir. Bu kapsamda ivazsız bir sağlararası kazandırmadan bahsedilemeyeceği için söz konusu kazandırmaların da MK m. 565 kapsamında tenkisi de mümkün olmayacaktır ${ }^{11}$.

Diğer yandan, bir hukuki işlemin karşılıksız kazandırma vasfını taşıyabilmesi için o kazandırmanın tamamen karşılıksız olması gerekli değildir ${ }^{12}$. Kimi durumlarda karş11ıksız kazandırmada bulunulan kimseye kısmi bir edimde bulunulmuş olabilir. $\mathrm{Bu}$ ihtimalde kısmi edimde bulunmuş olan kimsenin yerine getirmiş olduğu edimin karşı edimle karşılanmayan onun dışında kalan kısmı bağışlama teşkil edecektir ve bu ihtimalde yapılan işlem karma bağışlama olarak nitelendirilecektir ${ }^{13}$.

Ölünceye kadar bakma sözleşmesi de bağışlama sözleşmesi ile bir arada bulunabilir. Başka bir ifade ile, ölünceye kadar bakma sözleşmesi aynı zamanda bir karma bağışlama teşkil edebilir. Bu ihtimalde taraflar arasındaki sözleşmede edimin bir kısmı için ivaz tespit edilmiş ve diğer kısım için ise taraflar anlaşarak ivazsız kalmasını kararlaştırmışlardır ${ }^{14}$. Doktrindeki hakim görüş uyarınca, karma bağışlamanın varlığından bahsedebilmenin ilk şartı edimler arasında bir oransızlık

13 Akbıyık (n 10) 7. Karşılıksız kalan söz konusu kısmın bağışlama teşkil edebilmesi için bağışlama amacıyla yapılması gerektiği hususu da göz önünde bulundurulmalıdır.

14 Kocayusufpaşaoğlu (n 10) 393. 
veya değer farkının varlığıdır (objektif unsur) ${ }^{15}$. Edimler arasında sözleşmenin yapıldığı esnada oransızlığın olması halinde karma bağışlamanın varlığından söz edilebilir ${ }^{16}$. Edimler arasındaki oransızlığın hangi ölçüde olması gerektiği hususu ise doktrinde tartışmalıdır. Doktrindeki bir görüş, edimler arasındaki değer farkının miktarının başka bir ifade ile az veya çok olmasının karma bağışlamanın varlığı bakımından herhangi bir önem taşımadığını savunmaktadır ${ }^{17}$. Başka bir görüş ise, karma bağışlamadan bahsedebilmek için edimler arasındaki oransızlığın önemli ölçüde olması gerektiğini belirtmiştir ${ }^{18}$. Kanaatimizce, ilk olarak anılan görüş daha isabetlidir. Doktrinde de belirtildiği üzere karma bağışlamanın varlığ 1 için edimler arasındaki oransızlığın belli bir ölçüde olmasını aramak karma bağışlama kavramına yeni bir unsur eklemek anlamına gelebilir ${ }^{19}$. Bu noktada dikkat edilmesi gereken husus edimler arasındaki oransızlığın bağışlama amacıyla gerçekleştirilmiş olmasıdır ${ }^{20}$.

Karma bağışlamanın varlığından bahsedilebilmesinin diğer şartı ise sözleşmenin tarafları arasında oransızlık teşkil eden başka bir ifade ile ivazsız olan kısmın taraflardan birine karşılıksız kazandırma yapma amacıyla bırakılacağı konusunda

15 Kocayusufpaşaoğlu (n 10) 393; Akbıyık (n 10) 8,10-11; Eren ve Yücer Aktürk, (n 9) N. 846; Öztan (n 10) 103; Mustafa Dural ve Turgut Öz, Türk Özel Hukuku Cilt IV Miras Hukuku (Filiz 2019) N. 1140; Fikret Eren, Türk Medeni Hukukunda Tenkis Davası (Sevinç 1973) 86; Arık (n 6) 286; Necip Bilge, Borçlar Hukuku Özel Borç Münasebetleri (Banka ve Ticaret Hukuku Enstitüsü, 1971) 428; M. Kemal Oğuzman, Miras Hukuku (5. Bası, Filiz 1991) 260; Gülşah Vardar Hamamcıoğlu, Taşınır ve Taşınmaz Mülkiyetini Konu Alan Bă̆ışlama Sözleşmesi (2. Baskı, Adalet 2020) 361; Tülay Aydın Ünver, “ Miras Bırakanın Yasa Gereği Denkleştirmeye Tabi Olan Kazandırmaları", Prof. Dr. Şener Akyol'a Armağan (Filiz 2011) 111, 137; Wolf (n 7) 443-444; Akkök (n 6) 98-118; Kratz Brigitta, Präjudizienbuch OR Die Rechtsprechung des Bundesgerichts(1875-2015) (Schulthess Verlag, 2016) Art. 239 N. 6; BGE 98 II 352, 357-358; BGE 126 III 171, 173.

Ayrıca bkz.: Balmelli Marco, CHK - Handkommentar zum Schweizer Privatrecht Vertragsverhältnisse Teil 2: Arbeitsvertrag, Werkvertrag, Auftrag, GoA, Bürgschaft Art. 319-529 OR (3. Auflage, Schulthess 2016) Art. 521 N. 4. Yazar, bakım alacaklıs1 ile bakım borçlusunun edimleri arasında dengesizlik olması halinde karma bir ölünceye kadar bakma sözleşmesinin söz konusu olduğunu ve bu durumda sözleşmenin bağışlama hükümlerine tabi olacağını savunmaktadır.

16 Kocayusufpaşaoğlu (n 10) 393, 397; Akbıyık (n 10) 15; Arık (n 6) 286; Brigitta (n 15) Art. 239 N. 6. Sözleșmenin yapıldığı esnada karşılıklı edimlerin değeri dikkate alınarak bir oransızlığın olup olmadığının belirleneceği ve dolayısıyla ekonomik şartlar değiş̧ip bir edimin diğerine karşı değer kazanması halinin kazandırmayı sonradan karş1lıksız hale getirmeyeceği yönünde bkz.: Akbıyık (n 10) 15.

17 Kocayusufpaşaoğlu (n 10) 394; Akbıyık (n 10) 22.

18 İmre ve Erman (n 10) 276; Dural/Öz (n 15) N. 1140-1141; Öztan (n 10) 103,105; Şahin (n 1)166-167; Akartepe (n 1) 204, 208-209; Bülent Köprülü, Miras Hukuku Dersleri (2. Bası, Fakülteler 1985) 304. Ayrıca bkz.: Aydın Ünver (n 15) 137. Yazar, edimlerin arasındaki aşırı oransızlığın bilerek gerçekleştirilmiş ve mirasbırakanın karşılıksız kalan kısmın bağışlamayı amaçlamış olması gerektiğini belirtmiş̧ir.

19 Akbiyık (n 10) 22.

20 Kocayusufpaşaoğlu (n 10) 394; Akbıyık (n 10) 22; Eren ve Yücer Aktürk (n 9) N. 846; Öztan (n 10) 103; Dural/Öz (n 15) N. 1140. 
irade uyuşmasının olmasıdır ${ }^{21}$. Dolayısıyla anılan iki şartın bir arada bulunması halinde karma bağışlamanın varlığı kabul edilebilir. Bu noktada ölünceye kadar bakma sözleşmesi kapsamında bakım alacaklısının muhtemel yaşam süresi dikkate alındığında bakım alacaklısının yerine getirmiş olduğu edim ile bakım borçlusunun edimi arasında bakım borçlusu lehine bir oransızlık varsa ve söz konusu oransızlığın bakım borçlusuna terkine ilişkin bakım alacaklısının rıza göstermesi durumda bir karma bağışlamanın varlığından söz edilebilir ${ }^{22}$.

Ölünceye kadar bakma sözleşmesinin bir karma bağışlama teşkil ettiği durumlarda söz konusu sözleşme bakımından tenkise tabi olacak kısım yalnızca ivazsız kazandırma teşkil edecek olan kısımdır ${ }^{23}$. İvazsız kazandırma teşkil eden kısım bakım alacaklısının muhtemel yaşam süresi dikkate alınarak hesaplanacaktı2 ${ }^{24}$. Bakım alacaklısının muhtemel yaşam süresi hesaplandıktan sonra bakım borçlusuna devredilmiş olan malvarlığı değeri ve sözleşmenin kurulduğu zamanki koşullar dikkate alındığında bakım alacaklısının ifa edebileceği muhtemel bir değer tespit edildikten sonra iki değer arasındaki fark tenkise tabi tutulacaktır ${ }^{25}$.

Başka bir ihtimal olarak ise görünürde bir ölünceye kadar bakma sözleşmesi olsa da esasen taraflar arasında gizli bir bağışlama sözleşmesi olabilir. Bu durumda bakım alacaklısı ile bakım borçlusu arasında bir karma bağışlama değil muvazaalı bir bağışlama sözleşmesi vardır. Bu ihtimalde taraflar özünde bir bağışlama sözleşmesi olan hukuki işlemi ölünceye kadar bakma sözleşmesi olarak göstermek konusunda uzlaşmışlardır. Böyle bir durumda görünüşteki ölünceye kadar bakma sözleşmesi muvazaa sebebiyle kesin hükümsüz olacaktır ${ }^{26}$. Muvazaalı olan ölünceye kadar bakma sözleşmesinin ardındaki gizli bağışlama sözleşmesi bakımından ise sözleşmenin geçersizliğini etkileyen bir sebep olmadığı sürece söz konusu bağışlama sözleşmesi

21 Kocayusufpaşaoğlu (n 10) 395; Akbıyık (n 10) 25; Dural ve Öz (n 15) N. 1140; Öztan, (n 10) 103; Eren (n 15) 86; Eren ve Yücer Aktürk (n 9) 846; Eren (n 6) 931; Arık (n 6) 286; Bilge (n 10) 428; Vardar Hamamcioğlu (n 15) 362; Aydın Ünver (n 15) 137; Akkök (n 6) 98-118; Wolf (n 15) 444; Brigitta (n 15) Art. 239 N. 6; Bucher (n 6) 155; BGE 98 II 352, 357-358; BGE 126 III 171, 173.

Karma bağışlamanın tespiti kimi durumlarda çok kolay olmayabilir. Sözleşmede karşılıklı edimler arasında oransızlık olmasına rağmen söz konusu oransızlığın taraflardan birine bırakılması konusunda irade uyuşmasının varlığı açık olmayabilir. Bu durumda karma bağıșlamanın varlığı edimler arasındaki dengesizliğin oranı, tarafların irade beyanlarının güven ilkesine ve somut olayın koşullarına göre ve karşı tarafın irade beyanına nasıl anlam vermesi gerektiği hususları yorumlanarak tespit edilebilir. Doktrinde savunulan bir görüş uyarınca, karşılıklı edimler arasındaki oransızlık önemli ölçüde olmadığı durumda taraflar arasında da söz konusu oransızlık bakımından bir irade uyuşmasının varlığı da beklenemeyecektir. Bu durumda değer farkının varlığı ya taraflarca fark edilememiştir ya da ölünceye kadar bakma sözleşmesinin varlığı halinde bakım borçlusu kendi edimi için daha yüksek bir karşılık takdir edildiğini düşünecektir. Karşılıklı edimler arasındaki oransızlık önemli ölçüde ise somut olayda aksini gösteren bir emare bulunmadığı sürece edimler arasında lehine oransızlık bulunan tarafın kendisine yapılan bu beyanı karma bağıșlama olarak nitelendirmek gerekir. Bu yönde bkz.: Kocayusufpașaoğlu (n 10) s. 394; Akbiyık (n 10) 34-36. Ayrıca bkz.: Brigitta (n 15) Art. 239 N. 7.

22 Tunçomağ (n 2) 38; Oğuzman (n 15) 260; Çabri (n 10) N. 1524.

23 Ölünceye kadar bakma sözleșmesi kapsamında bakım alacaklısı olan mirasbırakanın bakım borçlusuna karșılıksız olarak devretmiş olduğu kısmın tenkis edilebileceği yönünde bkz.: Kocayusufpaşaoğlu (n 10) 766; Çabri (n 10) N. 1524; Frédéric (n 6) Art. 525 N. 2. Aynı yönde bkz.: Marco (n 15) Art 525 N. 4.

24 Tunçomağ (n 2) 155.

25 Tunçomağ (n 2) 155-156.

26 Muvazaanın sözleşmeye etkisi bakımından bkz. aşağıda dipnot 62'ye bağlı metin vd. 
geçerli olarak kabul edilecektir ve bu sözleşme saklı paylı mirasçıların saklı paylarını ihlal ettiği oranda tenkise tabi olacaktır ${ }^{27}$.

Ayrıca unutulmamalıdır ki MK m. 565 kapsamında tenkise tabi olan ivazsız bir sağlararası kazandırmanın olabilmesi hukuken geçerli bir kazandırma olması gerekmektedir ${ }^{28}$. Mirasbırakanın ölmeden önce yapmış olduğu sağlararası kazandırmanın geçersiz olması halinde anılan kazandırmanın konusu olan edim malvarlığından hiç çıkmamış olacağı için bu durumda kazandırmanın geçersizliğini ileri sürerek tamamen malvarlığına iadesi söz konusu olacaktır ${ }^{29}$. Dolayısıyla ölünceye kadar bakma sözleşmesi kapsamında gerçekleştirilen devrin geçersiz olması halinde saklı paylı mirasçılar tenkis davası açmak yerine geçersizlik sebebine bağlı olarak bakım alacaklısının ediminin tamamının terekeye iadesini sağlayabilirler. Özellikle ölünceye kadar bakma sözleşmesinin muvazaalı olduğu durumlarda saklı paylı mirasçılar tenkis davası yerine muvazaa sebebiyle sözleşmenin geçersizliğini ileri sürerek bakım alacaklısı mirasbırakanın karşı edim olarak bakım borçlusuna devretmiş olduğu malvarlığı değerinin tamamen terekeye iade edilmesini sağlayabilirler. $\mathrm{Bu}$ husus sonraki başlıklarda ayrıntılı olarak ele alınacaktır.

\section{Bakım Alacaklısının Sakı Payı İhlal Kastı ile Yaptığı Kazandırmaların Özellikleri}

MK m. 565/I b.4 uyarınca, mirasbırakanın saklı pay kurallarını etkisiz kılmak amacıyla yapmış olduğu kazandırmalar ölüme bağlı tasarruflar gibi tenkise tabi olur. $\mathrm{Bu}$ hüküm uyarınca sağlararası bir kazandırmanın tenkise tabi olabilmesi için söz konusu kazandırmanın saklı payları ihlal etmesinin yanında bir de kazandırma saklı paylı mirasçıların saklı paylarını zedeleme amacıyla yapılmış olmalıdır ${ }^{30}$. Sağlararası bir kazandırmanın MK m. 565/I b.4 uyarınca tenkis edilebilmesi için mirasbırakanın saklı payı etkisiz kılma kastı yeterlidir ${ }^{31}$; kazandırmanın mirasbırakanın ölümünden önceki bir yıl içinde yapılmış olması gerekli değildir. Benzeri şekilde, kazandırma lehdarının mirasçı ya da üçüncü bir kişin olması herhangi bir önem arz etmemektedir ${ }^{32}$. Bununla birlikte mirasbırakanın saklı payı etkisiz kılma amacı bulunmuyorsa o kazandırmanın MK m. 565/I b.4 uyarınca tenkisi de söz konusu olmayacaktır ${ }^{33}$.

\footnotetext{
Kocayusufpaşaoğlu (n 10) 402.

Çabri (n 10) N. 1493. Ayrıca bkz.: Yargıtay 2 HD, 940/1234 4.3.1963 (Olgaç (n 1) 111).

Çabri (n 10) N. 1493.

30 MK m. 565/I b.4'ün İsviçre Medeni Kanunu'ndaki karşılığı olan 527. maddenin 4. fikrası bakımından saklı payı ihlal kastı ile yapılmış olan sağlararası kazandırmaların objektif ve sübjektif unsuru bakımından bkz.: Wolf (n 15) 441.

31 İmre ve Erman (n 10) 274; Çabri (n 10) N. 1525,1527; Gökhan Antalya ve İpek Sağlam, Miras Hukuku (4. Bask1, Seçkin 2019) N. 1290.

32 Wolf (n 15) 439.

33 Çabri (n 10) 1525; Yargıtay 1 HD, 10437/13876 27.11.2012 (www.yargitay.gov.tr -Çevrimiçi- 21.02.2021) Anılan kararda Yargıtay tasarruf oranını aşan her kazandırmada saklı payı zedeleme kastının varlığından söz edilemeyeceği sonucuna varmıştır.
} 
Saklı payı ihlal edilmiş olan mirasçıların söz konusu tenkis talebinin başarıyla sonuçlanabilmesi için mirasbırakanın saklı pay kurallarını bertaraf etme kastının ispat edilmesi gerekmektedir. Bu kapsamda mirasbırakanın söz konusu kazandırmanın yapıldığı esnada diğer mirasçıların miras paylarının zarar göreceğini bilmesi ancak buna rağmen söz konusu kazandırmayı yapmasının ispatı yeterlidir ${ }^{34}$. Diğer yandan, mirasbırakanın söz konusu saklı pay kurallarını etkisiz kılma kastının kazandırma lehdarı tarafından bilinmesine veya bilinebilir olmasına gerek yoktur ${ }^{35}$.

Mirasbırakanın saklı payı ihlal kastı saklı payı ihlal eden kazandırmanın yapıldığı an mevcut olmalıdır ${ }^{36}$. Bununla bağlantılı olarak, söz konusu kazandırmanın yapıldığı esnada mirasbırakanın saklı paylı mirasçısının bulunması gerekmektedir ${ }^{37}$. Dolayısıyla ölünceye kadar bakma sözleşmesi kapsamında bakım alacaklısının bakım borçlusu lehine gerçekleştirmiş olduğu kazandırma bakımından saklı payı etkisiz kılma kastının varlığından bahsedilebilmesi için bakım alacaklısının saklı paylı mirasçısı mevcut olmalıdır. En azından cenin şeklinde muhtemel bir saklı paylı mirasçı bulunmalıdır; aksi takdirde bakım alacaklısının saklı pay kurallarını bertaraf etme kastından bahsedilemeyecektir ${ }^{38}$. Yargıtay tarafından verilmiş olan bir karara ${ }^{39}$ konu olayda mirasbırakan henüz davacıyla evlenmeden iki yıl önce taşınmazlarından birini ölünceye kadar bakma vaadi, bir diğerini ise satış suretiyle önceki eşinden olma çocuklarına devretmiştir. Yüksek Mahkeme temliklerin yapıldığı tarihte davacıyla evlilik olmadığı için mirasbırakanın saklı paya aşikâr bir tecavüz kastıyla hareket ettiğinden söz edilemeyeceği sonucuna varmıştır.

Mirasbırakanın saklı paylı mirasçılarının saklı paylarını ihlal kastı söz konusu kazandırmanın yapıldığı zaman dikkate alınarak belirlenebilir. Mirasbırakanın söz konusu kazandırmayı yaptığı sıradaki ekonomik koşullarının sonradan olumsuz şekilde değişmesi o kazandırmanın MK m. 565/I b. 4 gereğince tenkisine sebep

34 Kocayusufpaşaoğlu (n 10) 395; Eren ve Yücer Aktürk (n 9) N. 868; Çabri (n 10) N. 1528; Mehmet Ayan, Miras Hukuku (10. Bask1, Adalet 2020) 236-237; Öztan (n 10) 106; Dural/Öz (n 15) N. 1163; Akbıyık (n 10) 80; Eren (n 15) 93; K. Gültekin Tüfek, Miras Hukukunda Tenkis ve İade Davaları, (Olgaç Matbaası 1977) 149; Aydın Tekdoğan, "Sağlararası Tasarrufların Tenkisi”, (2017) 12 (133) Terazi Hukuk Dergisi 86, 96; Nar (n 10) 188-189; BGE 128 III 314,317. Aynı yönde bkz.: K. Nuri Turanboy, Mirasbırakanın Denkleştirme ve Tenkise Bağlı Sağlararası Hukuki İşlemleri (Yetkin 2010) 96, 99; Fankhauser Roland, CHK - Handkommentar zum Schweizer Privatrecht, Erbrecht, Art. 457-640 ZGB, (3. Auflage, Zürich, 2016, Art. 527 N. 5; Paul Piotet, Schweizeriches Privatrecht, Vierter Band, Erbrecht (Helbing \& Lichtenhahn 1978) 443; Wolf (n 15) 449 .

35 Serozan ve Engin (n 7) § 3 N. 49; Eren ve Yücer Aktürk (n 9) 869; İmre ve Erman (n 10) 274-275; Çabri (n 10) N. 1527; Dural ve Öz (n 15) N. 1162; Akbıyık (n 10) 80; Tunçomağ (n 2) 158; Eren (n 15) 94; Tüfek (n 34) 149; Tekdoğan (n 34) 96; Nar (n 10) 188; Vardar Hamamcioğlu (n 15) 154; Minnig Yannick, Orell Füssli Kommentar ZGB Kommentar Schweizerisches Zivilgesetzbuch (3. Auflage, Orell Füssli 2016) Art. 527 N. 6; Roland (n 34) Art. 527 N. 5 . Ayn1 yönde bkz.: Piotet (n 34) 444.

36 Ali Naim İnan, Şeref Ertaş ve Hakan Albaş, Miras Hukuku (10. Bası, Seçkin 2019) N. 1168; Yannick (n 35) Art. 527 N. 6; Roland (n 34) Art. 527 N. 5; Wolf (n 15) 451; BGE 128 III 314, 317.

37 Eren ve Yücer Aktürk (n 9) 868; Şahin (n 1) 169; Çabri (n 10) 1528; Turanboy (n 34) 98; Oğuzman, (n 15) 268; İnan,Ertaş ve Albaş (n 36) N. 1168; İmre ve Erman (n 10) 276; Wolf (n 15) 449; Nar (n 10) 190; Ali İhsan Özuğur, Tenkis, Mirasta Denkleştirme ve Muvazaa Davalarl (5. Bask1, Adalet 2015) s. 7; Eren (n 15) 93-94.

38 Şahin (n 1) 169-170; Ayan (n 34) 237-238; Eren (n 15) s. 93; Nar (n 10) 191; İnan,Ertaş ve Albaş (n 36) N. 1168.

39 Yargıtay 2 HD, 1990-10212/867, 22.01.1991 (Kazancı Hukuk- Çevrimiçi- 07.03.2021). 
olmaz ${ }^{40}$. Zira bir kazandırmanın MK m. 565/I b. 4 uyarınca tenkis edilebilmesi için o kazandırmanın yapıldığı esnada mirasbırakanın saklı payı ihlal amacı mevcut olmalıdır ${ }^{41}$. Bu amaç mirasbırakanın ekonomik koşullarından bağımsız olarak değerlendirilmelidir. Ancak mirasbırakan ileride ekonomik koşullarının bozulacağını biliyor veya öngörüyorsa ve söz konusu kazandırmasıyla gelecekte saklı payları ihlal edebileceğini öngörmesine rağmen tedbiren böyle bir kazandırmada bulunuyorsa bu durumda da mirasbırakanın saklı payı ihlal kastının mevcut olduğu sonucuna varılabilir $^{42}$.

Ölünceye kadar bakma sözleşmesi bakım borçlusunun edimi karşıllğıında yalnızca mülkiyet devri değil sınırlı ayni hak tesisi ${ }^{43}$, belirli malların kullanılması veya menfaatlerinin terk edilmesi ${ }^{44}$ ya da alacağın temliki de mümkün olduğu için bu tarz kazandırmaların da saklı payı ihlal kastı ile karşılıksız yapılmaları halinde saklı paylı mirasçıların MK m. 565/I b.4 uyarınca tenkis talebinde bulunmaları mümkündür ${ }^{45}$.

\section{Bakım Alacaklısının Saklı Payı İhlal Kastına Karine Teşkil Eden Durumlar}

\section{A. Bakım Alacaklısının Özel Bakım İhtiyacının Olmaması}

Yargıtay kararlarında ölünceye kadar bakma sözleşmesi kapsamında bakım alacaklısının saklı payı ihlal kastının var olabileceği hallerden birisi olarak bakım alacaklısının özel bakım ihtiyac1 ${ }^{46}$ tartışılmıştır. Bu konuyla alakalı Yargıtay tarafindan verilen bir kararda ölünceye kadar bakma sözleşmesinin yapıldığı esnada bakım alacaklısının özel bakıma muhtaç olmaması ve sözleşmenin yapılmasından sonra kısa bir süre yaşaması halinde saklı pay kurallarını bertaraf kastının mevcut olmadığı sonucuna varılmıştır ${ }^{47}$. Ancak, benzeri nitelikte başka bir kararda ise ölünceye kadar bakma sözleşmesinin yapıldığı esnada mirasbırakanın özel bakımı gerektirir bir halde bulunmamasının ve davalı oğlunun ahlaken babasına bakmakla yükümlü olması sebebiyle tarafların muvazaalı bir davranış içerisinde oldukları ve mirasbırakan sonradan felç olsa bile başlangıçtaki saklı payı giderme kastının ortadan

\footnotetext{
40 Çabri (n 10) N. 1529; Ayan (n 34) 238; Nar (n 10) 190; İnan, Ertaş ve Albaş (n 36) N. 1168; Eren (n 15$) 94$.

41 Bu yönde bkz. yukarıda dipnot 36.

42 Nar (n 10) 190; Turanboy (n 34) 99; İnan,Ertaş ve Albaş (n 36) N. 1168; Vardar Hamamcioğlu, (n 15) 154.

43 Mardin (n 6) 88; Eren (n 6) N. 2825.

44 Arık (n 6)285; Marco (n 15) Art. 521 N. 5; Bauer (n 6) Art. 521 N. 3

45 Tunçomağ (n 2) 158. Aynı yönde bkz.: Kocayusufpaşaoğlu (n 10) 403; Akbıyık (n 10) 82; Eren (n 15) 100.

46 Günay (n 2) 87-88; Tüfek (n 34) 154. Ölünceye kadar bakma sözleşmesinin kurulması sırasında özel bakıma muhtaç olunmamasının sözleşmenin saklı pay kurallarını bertaraf amacının varlığı için yeterli olmadığı yönünde bkz.: Antalya ve Sağlam (n 31) N. 1291

47 Yargıtay 2 HD, 1353/3152, 01.03.2007 (Kazancı Hukuk-Çevrimiçi-12.03.2021). Aynı yönde bkz.: Yargıtay 2 HD, 4108/7469, 4.6.2002 (Kazancı Hukuk-Çevrimiçi-12.03.2021); Yargıtay HGK, 1989-2-476/258 18.04.1990 (Kazancı Hukuk-Çevrimiçi- 12.03.2021).
} 
kalkmayacağı sonucuna varılmıştır ${ }^{48}$. Bakım alacaklısının özel bakım gereksiniminin tartışıldığı diğer bir kararda ${ }^{49}$ ise özel bakıma ihtiyaç duymayan siroz hastası bir kimse eşi tarafından özenle bakılmaktadır. Ancak mirasbırakan bir kısmı başka yerlerde oturan yedi çocuğu ile ölünceye kadar bakma akdi yapmış ve malvarlığının önemli bir kısmını aktarmıştır. Yargıtay bu durumları gözeterek mirasbırakanın ölünceye kadar bakma sözleşmesini eşin saklı payını bertaraf etmek amacıyla yaptığı sonucuna varmıştır.

Bakım alacaklısının özel bakım gereksinimin tartışılmış olduğu başka kararlarda ise Yargıtay, Türk Borçlar Kanunu hükümleri uyarınca ölünceye kadar bakma sözleşmesinden bahsedebilmek için bakım alacaklısı açısından aranan tek şartın onun gerçek kişi olması gerektiği, bakım alacaklısının özel bakıma muhtaç olması durumunun aranmasının ise yasal olarak öngörülmeyen bir şartın ilave edileceği anlamına geldiğini belirtmiştir ${ }^{50}$. Bu sebeple mirasçı olabilecek kimselerle yapılmış olan ölünceye kadar bakma sözleşmeleri bakımından bakım alacaklısının özel bakıma ihtiyacının bulunmamasının onun saklı payı ihlal amacı taşıdığının varlığı için yeterli olmadığı sonucuna varılmıştır. Hukuk Genel Kurulu da benzeri nitelikteki diğer bir kararında ölünceye kadar bakma sözleşmesi açısından özel bakım şartının aranmasının dahası özel bakım ihtiyacının mevcut olmadığı hallerde bakım alacaklısının mal kaçırma kastının kabul edilmesinin hakkaniyete aykırı olduğunu belirtmiştir ${ }^{51}$.

\section{B. Edimler Arası Dengesizlik}

Bakım alacaklısının saklı payı ihlal etme kastının varlığı bakımından Yargıtay kararlarında tartışılan başka bir nokta ise temlik olunan şeyin geliri ile bakım unsuru arasında bir orantı olması gerekliliğidir ${ }^{52}$. Bu kapsamda, bakım alacaklısı temlik olunan şeyin geliri ile kendisinin bakımını başka biri tarafından sağlayabilecekse bu durumda bakım alacaklısının saklı payı ihlal etme kastından bahsedilebilecektir. Bundan başka bakım alacaklısının yerine getirdiği edimin değeri bakım borçlusunun

48 Yargıtay 2 HD, 1986/9964, 13.11.1986 (Kazancı Hukuk-Çevrimiçi-12.03.2021). Benzeri yönde bkz.: Yargıtay 2 HD, 291/1473, 21.02.1977 (Kazancı Hukuk-Çevrimiçi-12.03.2021); Yargıtay 2 HD, 5750/6246, 31.10.1974 (Kazancı HukukÇevrimiçi-12.03.2021); Yargıtay 2 HD, 3927/3280, 14.04.1976 (Kazancı Hukuk-Çevrimiçi-12.03.2021); Yargıtay HGK, 1979-2-283/12, 16.01.1981 (Kazancı Hukuk-Çevrimiçi-12.03.2021). Son olarak anılan kararda Yargıtay, mirasbırakanın özel bakıma muhtaç olmadığını ve malvarlığının yarıya yakın kısmının eşe bağışlanması için makul ve haklı bir gerekçe olmadığını vurgulayarak mirasbırakanın söz konusu devir bakımından saklı payı etkisiz kılma kastının söz konusu olduğu sonucuna varmıștır.

Ayrıca bkz:: Yargıtay HGK, 1987-1-371/51, 27.01 .1988 (Kazancı Hukuk-Çevrimiçi-12.03.2021): Yargıtay anılan kararda ölünceye kadar bakma sözleşmesinin geçerliliği bakımından bakım alacaklısının özel bakıma muhtaç bulunması koşulunun yalnızca eşler arasında yapılan sözleşmeler bakımından geçerli olduğunu belirtmiştir.

49 Yargıtay HGK, 1977-2-625/287, 3.4.1978 (Kazancı Hukuk-Çevrimiçi- 12.03.2021).

50 Yargıtay 2 HD, 2838/3647, 17.03.2003 (Kazancı Hukuk-Çevrimiçi-14.03.2021). Aynı yönde bkz.: Yargıtay 2 HD, 13722/15421, 7.12.2000 (Kazancı Hukuk-Çevrimiçi-14.03.2021); Yargıtay 2 HD, 46/1689, 8.2.1990 (Kazanc1 HukukÇevrimiçi-14.03.2021); Yargıtay 2 HD, 1353/3152, 01.03.2007 (Kazancı Hukuk-Çevrimiçi-14.03.2021); Yargıtay 2 HD, 5145/10933, 15.11.1990 (Akartepe (n 1) 238-239); Yargitay 2 HD, 6121/12779, 11.12.1990 (Akartepe (n 1) 239-240).

51 Yargıtay HGK, 1987-2-814/247, 16.03.1988 (Kazancı Hukuk-Çevrimiçi-14.03.2021).

52 Yargıtay 2 HD, 291/1473, 21.02.1977 (Kazancı Hukuk-Çevrimiçi-14.03.2021); Yargıtay 2 HD, 1622/1743, 1.3.1977 (Kazancı Hukuk-Çevrimiçi-14.03.2021). Aynı yönde bkz.: Tüfek (n 34) 154; Günay (n 2) 91-92. 
ediminin kapitalize değerinden daha fazla ise edimler arasında bir oransızlık olduğu sonucuna varılacaktır ${ }^{53}$.

Doktrinde bir görüş de eşlerin birbirlerine bakıp gözetme yükümlülükleri söz konusu olduğu için normalin üzerinde bir bakım gerektiği takdirde eşler arasında ölünceye kadar bakma sözleşmesinin söz konusu olabileceğini; bununla birlikte eşin kendi ödevi de göz önünde tutularak bütün verilen mallarla eşin kendi edimi kıyaslandığı takdirde iki edim arasında oransızlık bulunması halinde eşler arasındaki temliklerin tenkis edilebileceğini savunmaktadır ${ }^{54}$.

\section{Bakım Alacaklısının Malvarlığının Tamamı veya Tamamına Yakınını Devri}

Ölünceye kadar bakma sözleşmesi kapsamında bakım alacaklısının malvarlığının tamamını ya da tamamına yakın bir kısmını bakım borçlusuna devretmesi halinde de bakım alacaklısının saklı payı ihlal kastının varlığından bahsedilir ${ }^{55}$. Yukarıda anılan Yargıtay Hukuk Genel Kurulu tarafindan verilmiş olan kararda ${ }^{56}$, eşi tarafından bakım ve gözetimi sağlanan bir siroz hastası, ona bakan eşi ile değil de başka eşten doğmuş olan yedi çocuğu ile ölünceye kadar bakma sözleşmesi yapmış ve malvarlı̆̆ının önemli bir kısmını bu yolla devretmiş̧ir. Bakım alacaklısı bir süre sonra ise bir kısım taşınmazlar üzerinde ipotek tesis etmiştir. Yüksek Mahkeme bir kimsenin geliri ile kendisine baktırması mümkünken ölünceye kadar bakma sözleşmesi ile malvarlığının önemli bir kısmını çocuklarına aktarmasının iyiniyetli olmadığını gösteren bir delil olduğu ve ölünceye kadar bakma sözleşmesinin sırf eşin saklı payını ihlal kastı ile yapıldığının yoruma ihtiyaç gerektirmeyecek bir biçimde açık olduğu ve tenkis hükümleri gereğince işlem yapılması gerektiği sonucuna varmıştır. Benzeri nitelikteki bir karara ${ }^{57}$ konu olan uyuşmazlıkta ise bakım alacaklısı ölünceye kadar bakma sözleşmesi uyarınca malvarlığının tamamını bakım borçlusu olan davalıya devretmiştir. Yargıtay bakım alacaklısının özel bakıma ihtiyacı olmaması ve malvarlığının hepsini bakım alacaklısına devretmesi sebebiyle ölünceye kadar bakma sözleşmesinin saklı payı zedeleme amacına

53 Eren (n 15) 98; Bauer (n 6) Art. 525 N. 5. Yargitay 1 HD, 2016-10444/4121, 26.06.2009 (Kazanc1 HukukÇevrimiçi-17.03.2021): “... Somut olaya gelince; mirasbırakan adına kayıtlı dava dışı taşınmazların dava tarihindeki değerleri toplamı 155.707.88 TL, çekişme konusu davalıya devredilen taşınmazların dava tarihindeki değerleri toplamı ise; 274.242.8 TL olup,yukarıda değinilen ilkeler ve olgular gözetildiğinde, davalıya yapılan temlikler bakımından makul sınırın aşıldığı, mirasbırakanın çekişmeli taşınmazlardan bir kısmını devrederek bakımını sağlayabilecek iken, adına kayıtlı taşınmazlarından çok değerli olanları devrettiği, bu nedenle temliklerin mirasçılardan mal kaçırma amaçlı olarak yapıldı̆̆ının kabulü gerekmektedir...”.

54 Dalamanlı (n 1)131.

55 Günay (n 2) 88-89,91-92; Öztan (n 10) 107; Tüfek (n 34)151; Özuğur (n 37$) 8$.

56 Yargıtay HGK, 1977-2-625/287, 03.04.1978 (Kazanc1 Hukuk-Çevrimiçi-19.02.2021). Aynı yönde bkz.: Yargıtay 2 HD, 5750/6246, 31.10.1974 (Kazancı Hukuk-Çevrimiçi-19.02.2021); Yargıtay 2 HD, 6716/7776, 4.10.1985 (Kazancı HukukÇevrimiçi-19.02.2021): "Miras bırakanın tüm mal varlığını davalılara temlik etmiş olması ve tapudaki satış bedelleri ile gerçek değerleri arasında fahiş ( Açık) fark bulunması, temlikin davacıdan mal kaçırma, başka bir anlatımla saklı payı zedeleme kastiyla hareket edildiğinin objektif delilleridir."

57 Yargıtay 2 HD, 3027/3280, 14.04.1976 (Kazancı Hukuk-Çevrimiçi-21.02.2021). Aynı yönde bkz.: Yargıtay 2 HD, 5750/6246, 31.10.1974 (Kazancı Hukuk-Çevrimiçi-21.02.2021). 
yönelik olduğunu kabul etmiştir. Aynı nitelikte başka bir karara ${ }^{58}$ konu uyuşmazlıkta ise mirasbırakan ölümünden bir hafta önce bütün malvarlığını ölünceye kadar bakma sözleşmesi kapsamında eşine devretmiştir. Yüksek mahkeme mirasbırakanın hastalık durumu ve oğluyla arasının açık olması sebebiyle mirasbırakanın saklı payı ihlal kastının olduğu sonucuna varmıştır.

Aynı hususun tartışıldığı bazı kararlarda ise Yargıtay bir kimsenin malvarlı̆̆ının tümünü ya da ona yakın bir kısmını ölünceye kadar bakma sözleşmesi ile başkasına devretmesinin olayların akışına ters düştüğü takdirde gizli bağış niteliği taşıdığ 1 sonucuna varmıştır ${ }^{59}$. Bu kapsamda Yargıtay anılan kararların birinde bakım alacaklısının bakım borçlusuna devretmiş olduğu taşınmazların değerinin terekenin değerinin altı katından fazla olduğu durumun "olayların akışına ters düştüğü" ve dolayısıyla gizli bağış niteliği taşıdığını belirtmiştir ${ }^{60}$.

\section{Değerlendirme}

Yarg1 kararları uyarınca belirli durumların varlığ alacaklısının saklı payı ihlal kastı ile hareket ettiği sonucuna varılmıştır. Bu hallerden biri bakım alacaklısının özel bakım ihtiyacı içerisinde olmasıdır. Yargıtay bazı kararlarında sözleşmenin kurulması esnasında bakım alacaklısının özel bakım ihtiyacı içerisinde olması gerekliliğini belirtmişken diğer bazı kararlarında böyle bir gereklilikten bahsedilmemiştir. Kanaatimizce sözleşmenin geçerliliği bakımından bakım alacaklısının ölünceye kadar bakma sözleşmesinin kurulması esnasında özel bakım ihtiyacı içerisinde olmasına gerek yoktur. Zira ölünceye kadar bakma sözleşmesinin BK m 611'de yer alan yasal tanımı incelendiğinde sözleşmenin kurulması bakımından böyle bir gereklilikten bahsedilmediği görülmektedir. BK m 611'de yalnızca bakım alacaklısının bakılıp gözetilmesinden bahsedilmiştir. Dolayısıyla yasal olarak böyle bir gereklilik aranmamışken yine de sözleşmenin kurulması esnasında özel bakım ihtiyacının varlığını aramak ölünceye kadar bakma sözleşmesinin kurulabilmesi için ek bir şart getirmek anlamına gelecektir ${ }^{61}$.

58 Yargitay HGK, 1972-2-173/97, 9.2.1974 (Olgaç (n 1) 117).

59 Yargıtay 2 HD, 291/1473, 21.02.1977 (Kazancı Hukuk-Çevrimiçi-30.03.2021); Yargıtay 2 HD, 1622/1743, 1.3.1977 (Kazancı Hukuk-Çevrimiçi-30.03.2021).

60 Yargıtay 2 HD, 291/1473, 21.02 .1977 (Kazancı Hukuk-Çevrimiçi-31.03.2021): “ Öte yandan temlik edilen şeyin geliri ile hizmet karşılığı arasında adil bir nisbetin bulunması icap eder. Zira, temlikte bulunan kişi gelirinin bir kısmı ile zaten bu bakım görevini davalı tarafa veya ücüncü bir kişiye yaptırabilir. Buna rağmen büyük bir servetin nakline yol açacak şekilde bir muameleye başvurması gerçek anlamıyla ölünceye kadar bakma sözleşmesi olarak kabul olunamaz. Böyle bir tutum saklı payı giderme kastının objektif delili sayllır. Temlik edilen taşınmazların değeri 580.000 TL. dir.

Diğer taraftan, bir kimsenin mal varllğının tümünü veya ona yakın bir kısmını ölünceye kadar bakma sözleşmesi ile başkasına devretmesi hali de olayların akışına ters düştüğü takdirde gizli bağış niteliği taşır. Nitekim temlik dışı tereke 90.000 TL. olup, ölünceye kadar bakma adı altında verilen taşınmazların değerinin altıda birinden azdır."

${ }_{61}$ Bakım alacaklısının sözleșmenin kurulması esnasında özel bakım ihtiyacı içerisinde olması yasal olarak bir gereklilik olmamakla birlikte; özel bakım ihtiyacı içerisinde olmayan bir kimsenin ölünceye kadar bakma sözleşmesi yapması ve sözleşmenin diğer tarafının da bakım alacaklısının bakım ihtiyacının olmaması sebebiyle bakım borcunu yerine getirmemesi halinde sözleşmenin muvazaalı olması hususu gündeme gelebilir.

Ayrıca bkz.: Eviz (6) 97 vd. Yazar, sözleşmenin devamı esnasında mirasbırakanın sözleşmeye aykırılık sebebiyle bakım borçlusu aleyhine dava açmaması halinde sözleşmenin ivazlı olduğunu ve bakım borcunun yerine getirildiğini kabul etmektedir. 
Yargı kararları uyarınca bakım alacaklısının saklı payı ihlal kastının varlığına karine teşkil eden diğer durumlar ise edimler arası oransızlık ve bakım alacaklısının malvarlığının tamamını ya da büyük bir kısmını bakım borçlusuna devretmesidir. Kanaatimizce yalnızca bakım alacaklısı ile bakım borçlusunun edimleri arasında bir dengesizliğin bulunması ya da bakım alacaklısının malvarlığının tamamını veya büyük bir kısmını bakım borçlusuna devretmiş olması durumu göz önünde bulundurularak bakım alacaklısının saklı pay kurallarını etkisiz kılmak amacıyla hareket ettiği sonucuna varmak doğru olmayacaktır. Şöyle ki, bakım alacaklısı ve bakım borçlusunun edimleri arasında bir oransızlık olması ölünceye kadar bakma sözleşmesinin karma bağışlama niteliğini haiz olduğuna işaret eden bir durumdur. Ancak ölünceye kadar bakma sözleşmesinin karma bağışlama niteliğini haiz olması bakım alacaklısının mutlaka saklı pay kurallarını etkisiz kılmak amacıyla hareket ettiği sonucunu doğurmaz. Diğer yandan bakım alacaklısının malvarlığında tek bir malvarlığı değerinin mevcut olduğu bir durumda bu malvarlığı değeri bakım alacaklısının ölünceye kadar bakma sözleşmesinden doğan borcu bakımından karşı edim niteliğini haiz olabilir. Benzeri şekilde somut olayda bakım alacaklısı ancak malvarlığının büyük bir kısmını bakım alacaklısına devrederek ölünceye kadar bakma sözleşmesi kapsamında borcunu ifa edebilecek durumda olabilir. Dolayısıyla bu ihtimallerde bakım alacaklısı malvarlığının tamamını ya da büyük bir kısmını bakım borçlusuna devretmiş olsa da saklı payı ihlal kastı ile hareket etmediği aşikardır. Yargı kararları uyarınca saklı payı ihlal kastına karine teşkil eden her iki durum bakımından da bakım alacaklısının bu amaçla hareket ettiği sonucuna varabilmek için somut olayın özellikleri dikkate alınarak saklı payı ihlal kastını gösteren başka hususların varlığı aranmalıdır. Örneğin, bakım alacaklısı ile bakım borçlusunun edimleri arasındaki oransızlığın mevcut olduğu bir ölünceye kadar bakma sözleşmesinin varlığı ihtimalinde bakım alacaklısı malvarlığının tümünü bakım borçlusuna devretmişse ve yakın çevresine yıllardır görüşmediği ve bir türlü boşanamadığı eşinin mirasından pay almasını istemediğini belirtmişse bu durumda bakım alacaklısının saklı payı ihlal kastı ile hareket ettiği sonucuna varılabilir.

\section{Bakım Alacaklısının Saklı Payı İhlal Kastı ile Yaptığı Kazandırmaların Muvazaa Açısından Değerlendirilmesi}

Bakım alacaklısının saklı pay kurallarını ihlal etmek amacı ile yapmış olduğu karşılıksız kazandırmaların bir kısmı -muris muvazaası olarak anılan- muvazaalı temliklerden oluşmaktadır. Örneğin, ölümü halinde çocuklarının mirasından hiçbir pay almasını istemeyen bir baba bir arkadaşı ile bağışlama sözleşmesi yapmak yerine ölünceye kadar bakma sözleşmesi yaparak malvarlığındaki tüm taşınmazları ona devredebilir. Bu durumda tarafların esas amacı bağışlama sözleşmesi yapmaktadır. Ancak söz konusu bağışlama sözleşmesi ölünceye kadar bakma sözleşmesinin 
arkasına gizlenmiştir. Doktrindeki hakim fikir ${ }^{62}$ ve Yarg1 kararlar1 ${ }^{63}$ uyarınca bu durumda görünüşteki ölünceye kadar bakma sözleşmesi muvazaa sebebiyle geçersizdir; gizli bağışlama sözleşmesi ise geçerlidir. Ancak gizli işlemin şekle tabi olduğu durumlarda söz konusu işlemin geçerli olarak kabul edilebilmesi için yasal olarak öngörülen şekilde yapılması gerekmektedir ${ }^{64}$. Örnekte olduğu gibi bakım alacaklısının ölünceye kadar bakma sözleşmesi kapsamında tüm taşınmazlarını bakım borçlusu arkadaşına devretmesi halinde görünüşteki ölünceye kadar bakma sözleşmesi muvazaa sebebiyle geçersiz olacaktır. Ölünceye kadar bakma sözleşmesinin altında

62 Eren ve Yücer Aktürk (n 9) N. 872; İmre ve Erman (n 10) 295; Kocayusufpaşaoğlu (n 10). 396; Ayan (n 34) 240; Öztan (n 10) 108; Dural ve Öz (n 15) N. 1143; Eren (n 15) 95; Köprülü, (n 18) 309; İnan,Ertaş ve Albaş (n 36) N. 1137; Antalya ve Sağlam (n 31) N. 1294; Çabri (n 10) 1535; Serozan ve Engin (n 7)§3 N. 30; Andreas von Tuhr, Borçlar Hukukunun Umumi Kısmı Cilt:1-2, Cevat Edege (Çev) (Yargıtay 1983) 274; Murat Topuz, "Yargıtay Kararları Işığında Muris Muvazaasının Varlığını Gösteren Emareler" (2016) 15(2) İstanbul Kültür Üniversitesi Hukuk Fakültesi Dergisi (Prof. Dr. M. İlhan Ulusan'a Armağan, Cilt II) 709, 713; Süleyman Yılmaz, Muris Muvazaası (Yetkin 2021) 110, 116,145; Rona Serozan, Başak Baysal ve Kerem Cem Sanl, Borçlar Hukuku Özel Bölüm (3. Bası, On İki Levha 2018) N. 995.

63 Yargıtay İBK, 1/2, 1.4.1974 (Kazancı Hukuk-Çevrimiçi- 01.04.2021): “...Muvazaa nedeniyle satış sözleşmesi geçersiz sayllsa bile gizli hibe akti geçerli olacağından mirasçının Borçlar Kanunu 'nun 18. maddesine dayanarak açacağı davada yarar bulunmadı̆̆ ve bu nedenle bir sonuç doğurmayacă̆ düşüncesini de kabul etmek olanaksızdır. Gerçekten böyle bir davayı açacak kimsenin, davada yararının bulunması zorunludur. Ve ilke olarak da gizli akit geçerlidir. Ancak gizli aktin geçerli sayılabilmesi için tüm koşulların oluşmuş olması zorunludur. İçtihadı birleştirmeye konu, tapuda kayıtll bir taşınmaz malın muvazaalı olarak satı̧̧ıır. Böyle bir durumda gizli aktin geçerli sayılabilmesi için gizli akit, biçim koşuluna ( şekil şartına ) bağlı ise biçim koşulunun da gerçekleşmiş olmasında zorunluluk vardır. Aksi durumda hibe sözleşmesinin varlığından söz edilemez. Çünkü tapu memuru önünde açıklanan irade, bir ivaz karşıllğ̆ mülkiyetin aktarılması iradesidir ki, sadece bu iradeye resmiyet verilmiștir. Satışa ilișkin resmi ișlemin gizli akti de içine alacağı kabul edilemez... ". Benzeri yönde bkz.: Yargıtay IBGK, 1989-1/2, 16.03.1990 (Kazancı Hukuk-Çevrimiçi- 01.04.2021); Yargıtay 1 HD, 86/609, 23.01.2002 (Kazanc1 Hukuk-Çevrimiçi-01.04.2021); Yargıtay 1 HD, 2018-276/3741, 14.07.2020 (Kazanc1 HukukÇevrimiçi-01.04.2021); Yargıtay 1 HD, 2016-6758/3627, 8.7.2020 (Kazancı Hukuk-Çevrimiçi-01.04.2021); Yargıtay 1 HD, 2016-11011/4023, 20.06.2019 (Kazancı Hukuk-Çevrimiçi-01.04.2021); Yargıttay 1 HD, 5387/8782, 2.7.1992 (Kazanc1 Hukuk-Çevrimiçi-01.04.2021); Yargıtay HGK, 1-251/245, 28.04.1999 (Kazancı Hukuk-Çevrimiçi- 01.04.2021); Yargıtay 1 HD, 6959/7595, 13.06.2002 (Kazancı Hukuk-Çevrimiçi-01.04.2021).

${ }_{64}$ İmre ve Erman (n 10) 295; Ayan (n 10) 240; Dural ve Öz (n 15) 1145; Eren (n 15) 95; Beșir Acabey, "Yargıtay Kararları Işığında Muris Muvazaası”, Tuğçe Tuzcuoğlu ve A. Hulki Cihan (eds), Yargıtay Kararları Işı̆̆ında Güncel Medeni Hukuk Problemleri Sempozyumu Bildirileri 8-9 Kasım 2018 (On İki Levha 2019) 471, 478; Antalya ve Sağlam (n 31) N. 1294; Serozan, Baysal ve Sanlı, (n 61) N. 995. 
gizlenen bağışlama sözleşmesi ise şekle aykırı ${ }^{65}$ olduğu için geçersiz olacaktır ${ }^{66}$. Bu durumda gizli bağışlama sözleşmesine dayanılarak gerçekleştirilen devrin tenkisi de söz konusu olmayacaktır. Zira bir kazandırmanın tenkise tabi olabilmesi için söz konusu kazandırmanın geçerli olması gerekirir ${ }^{67}$ Örnekteki bağışlama sözleşmesi şekle aykırı olduğu için bu sözleşmeye dayanılarak tapuda gerçekleştirilmiş olan tescil de yolsuz bir tescil olacaktır. Dolayısıyla bu ihtimalde saklı paylı olsun ya da olmasın mirasbırakanın mirasçılar $1^{68} \mathrm{MK}$ m. 1025 uyarınca tapu sicilinin düzeltilmesi davası açarak sözleşmeye konu olan taşınmazların tamamen terekeye iadesini ${ }^{69}$ sağlayabilirler ${ }^{70}$. Ancak ölünceye kadar bakma sözleşmesi yapılmış olmasına rağmen taşınmazın devri gerçekleşmediği ihtimalde tapu kaydının düzeltilmesi söz konusu olmayacaktır ${ }^{71}$.

${ }_{65}$ BK m 288/II uyarınca, bir taşınmazın veya taşınmaz üzerindeki ayni bir hakkın bağışlanması söz vermenin geçerliliği, ancak resmi şekilde yapılmış olmasına bağlıdır.

Ancak șekle aykırılığın ileri sürülmesi MK m. 2 kapsamında hakkın kötüye kullanılması teșkil ediyorsa söz konusu sözleşme geçerli hale gelmiş sayılır. Bu durumda söz konusu sözleşme uyarınca yapılan devir tapu kaydının düzeltilmesi yoluyla terekeye iade edilemeyecektir. Saklı paylı mirasçıların bu ihtimalde izleyebileceği tek yol MK m. 565/I b. 3 veya b. 4 uyarınca tenkis talebinde bulunmaktır. Bu yönde bkz.: Necip Kocayusufpaşaoğlu, Miras Hukuku 2. ve 3. Bastlara Ek Kitap (Filiz 1992) 27-28.

Ayrıca bkz.: Yaşar Karayalçın, Mirasbırakanın Muvazaası mı? Tasarruf Özgürlüğ̈̈ ve Saklı Payın Korunması mı? (Turhan 2000) 57. Yazar, muvazaalı bir satışın varlığı halinde görünürde satış sözleșmesinin gerçekte de bir bağışlama sözleşmesinin mevcut olduğu hallerde tarafların taşınmaz üzerinde mülkiyeti devir iradesini resmi şekle uygun olarak yetkili makam önünde beyan ettiğini, bu sebeple bağış yerine satış kelimesinin kullanılmasının taşınmazın mülkiyeti bakımından geçersizlik sebebi sayılamayacağını belirtmektedir.

66 Yargıtay kararları ve doktrinde kabul edildiği üzere muvazaalı satış ya da ölünceye kadar bakma sözleşmesinin arkasındaki gizli bağışlama sözleşmesine dayanılarak gerçekleştirilmiş olan taşınmaz devrinin şekle ayrılık sebebiyle hükümsüz sayılması bazı durumlarda mirasbırakanın iradesiyle uyuşmayabilir. Şöyle ki Yargıtay Hukuk Genel Kurulu'nun vermiş olduğu bir karar uyarınca mirasbırakan sağlığında mirasçıları ile paylaştırma amacıyla muvazaalı işlemlerle malvarlığı devrinde bulunduğu ihtimalde mirasçılar arasında dengeli bir şekilde paylaşım yapıldığ arasında makul ölçüde bir farklılık olsa bile mirasbırakanın mirasçılardan mal kaçırma ve onları aldatma kastı olmadığı için muris muvazaasından söz edilemeyecektir. Dolayısıyla böyle bir durumda söz konusu taşınmaz devri șekle aykırı olsa bile mirasbırakanın mirasçılarından mal kaçırma kastından bahsedilemeyeceği için muris muvazaasından bahsedilemeyecek ve tapu kaydının düzeltilmesi yoluna gidilemeyecektir. Bu yönde bkz.: İmre ve Erman (n 10) 297-298; Yargitay HGK, 1-295/333, 16.06.2010 (Kazancı Hukuk-Çevrimiçi-10.04.2021). Aynı yönde bkz.: Yargıtay 1 HD, 4662/8144, 28.06.2012 (Kazancı Hukuk-Çevrimiçi-10.04.2021); Yargıtay 1 HD, 6777/7862, 11.07.2007 (Kazancı Hukuk-Çevrimiçi-10.04.2021); Yargıtay 1 HD, 6406/7841, 5.7.2006 (Kazancı Hukuk-Çevrimiçi-10.04.2021); Yargıtay 1 HD, 1996-16152/631, 22.01.1997 (Kazancı Hukuk-Çevrimiçi-10.04.2021); Yargıtay 1. HD, 1.3.2006, E. 2005/14705, K. 2006/2028 (Kazanc1 HukukÇevrimiçi 10.04.2021)

Bu uygulamanın yasal dayanağı olmadığı yönünde bkz.: Dural ve Öz (n 15) N. 1156.

${ }_{67}$ Eren ve Yücer Aktürk (n 9) N. 872; İmre ve Erman (n 10) 299; Akbıyık (n 10) 82; Eren (n 15) 95-96.

68 Ayrıca bkz.: Yargıtay İBGK, 1/2, 1.4.1974 (Kazancı Hukuk-Çevrimiçi-1.4.2021). Yargıtay anılan kararda, bir kimsenin mirasçısını miras hakkından yoksun etmek amacıyla yapmış olduğu muvazaalı işleme karşı saklı pay sahibi olsun ya da olmasın miras hakkı çiğnenen tüm mirasçıların görünüșteki ișlemin muvazaalı olduğu, gizli sağıș sözleșmesinin de șekle aykırı olduğunu ileri sürerek dava açabilecekleri sonucuna varmıştır. Doktrinde ise bu karar, mirasbırakanın tasarruf nisabı içerisinde serbestçe tasarruf edebileceği ve bu anlamda mirasçılarından mal kaçırma kastından bahsedilemeyeceği; saklı payı olmayan mirasçının mirasbırakanın tasarruflarına karşı hukuken korunan hakları olmadığı; bu sebeple haklarına tecavüzden dolayı dava hakkından söz edilemeyeceği ve "mirasçıyı miras hakkından yoksun etme" sözünün ancak saklı paylı mirasçılar için bir anlam ifade edeceği yönünde eleştirilmektedir. Bu yönde bkz:: Oğuzman (n 15) 263; Kocayusufpaşaoğlu (n 64) 27-28. Kanaatimizce de hukukumuzda yalnızca saklı paylı mirasçıların mirasbırakana karşı hukuken korunan hakları olduğu için "mirasçıdan mal kaçırma" ve "mirasçıyı miras hakkından yoksun etme" ifadesi yalnızca saklı paylı mirasçılar bakımından hüküm ifade etmelidir.

69 Muvazaa sebebiyle açılacak olan tapu kaydının düzeltilmesi davasının bașarıyla sonuçlanması halinde dava konusu taşınmaz tamamen terekeye iade olacaktır. Ancak Yargıtay tarafından verilmiş olan bir kararda muris muvazaası hukuksal nedenine dayanılarak açılan davalarda tapu iptal ve tescili istenebileceği gibi tazminat da istenebileceğini kabul edilmiştir. Bu yönde bkz.: Yargıtay 1 HD, 580/2568, 8.3.2012 (Kazancı Hukuk-Çevrimiçi-12.04.2021).

70 Eren ve Yücer Aktürk (n 9) N. 872; Serozan ve Engin, (n 7) §3 N. 30; İmre ve Erman (n 10) 295-296; Öztan (n 10) 108; Dural ve Öz (n 15) N. 1145; Eren (n 15) 96; Çabri (n 10) N. 1535. Aynı yönde bkz.: Ayan (n 34) 241.

${ }^{71}$ Ayan (n 34) 242; Yargıtay 1 HD, 2009-12612/3260, 23.03.2010(Kazancı Hukuk-Çevrimiçi- 13.04.2021). 
Yargıtay Hukuk Genel Kurulu 1974 tarihli İçtihadı Birleştirme Kararı'nda ${ }^{72}$ yalnızca tapuya kayıtlı taşınmaz bakımından uygulanacağı sonucuna varmıştır. Muvazaalı sözleşmenin arkasındaki işlemin şekle tabi olmaması halinde ise saklı paylı mirasçıların muris muvazaası sebebiyle iptal davası açma imkanı söz konusu değildir ${ }^{73}$. Ancak şartların varlığı halinde MK m. 565/I b.4 uyarınca tenkis talebinde bulunması mümkündür. Örneğin, muvazaalı bir ölünceye kadar bakma sözleşmesi kapsamında bakım alacaklısı saklı paylı mirasçılarının haklarını zedelemek kastıyla malvarlığında yer alan antika bir vazonun zilyetliğini bir arkadaşına devretmiş olabilir. Bu durumda ölünceye kadar bakma sözleşmesi muvazaa sebebiyle geçersiz olacaktır. Bu sözleşmenin arkasında gizlenen elden bağışlama ise şekle tabi olmadığ için geçerli olacaktır. Bakım alacaklısı vefat ettiğinde saklı paylı mirasçılar saklı paylarını ihlal eden söz konusu devir için TBK m 615/III'e dayanarak MK m. 565/I b.4 uyarınca tenkis davası açabilirler. Mirasbırakanın yapmış olduğu kazandırma bakımından saklı payı ihlal kastı söz konusu olmadığı ya da ispat edilemediği durumda tenkis davası MK m. 565/I b.3'e dayandırılabilir ${ }^{74}$.

Mirasbırakanın mirasçılarından mal kaçırmak amacıyla yapmış olduğu bir ölünceye kadar bakma sözleşmesi ile bağlantılı olarak gerçekleştirmiş olduğu devirlerin muvazaalı olup olmadığının değerlendirilmesi bakımından Yargıtay mirasbırakanın yaşı, fiziki durumu, içinde yaşadığı ailenin genel durumu, aile ilişkileri, temlik edilen malvarlığı değerinin tüm malvarlığına oranını birlikte değerlendirerek gerçek temlik nedenini araştırmıştır ${ }^{75}$. Yapılan değerlendirme neticesinde bakım alacaklısı mirasbırakanın söz konusu devri mirasçılardan mal kaçırmak amacıyla yaptığı ve bağış amacının üstün tutulduğu sonucuna ulaşıldığında ise söz konusu devrin muvazaalı olduğu ve iptal edilmesi gerektiği sonucuna ulaşılmıştır.

72 Yargıtay HGK, 4-359/405, 8.6.2011 (Kazancı Hukuk-Çevrimiçi-15.04.2021).

73 Bu durumda gizli işlemin geçerli kalacağı yönünde bkz.: Yılmaz (n 61) 111.

74 Eren ve Yücer Aktürk (n 9) N. 873.

75 Yargıtay 14 HD, 4324/5566, 29.04.2008 (Kazancı Hukuk-Çevrimiçi-15.04.2021); Yargıtay 1 HD, 2016-10225/228, 16.01.2020 (Kazancı Hukuk-Çevrimiçi-15.04.2021); Yargıtay 1 HD, 2016-12820/ 171, 14.01.2020 (Kazanc1 HukukÇevrimiçi-15.04.2021); Yargıtay 1 HD, 2016-11619-/5628, 4.11.2019 (Kazancı Hukuk-Çevrimiçi-15.04.2021); Yargıtay 14 HD, 2017-2073/4654, 22.05 .2019 (Kazancı Hukuk-Çevrimiçi-15.04.2021); Yargıtay HGK, 2017-1211/377, 28.03.2019 (Kazancı Hukuk-Çevrimiçi-15.04.2021); Yargıtay 14 HD, 2016-10120/314, 14.01.2019 (Kazancı HukukÇevrimiçi-15.04.2021); Yargıtay 1 HD, 537/980, 19.02 .2018 (Kazancı Hukuk-Çevrimiçi-15.04.2021); Yargıtay 1 HD, 2015-705/3889, 5.7.2017 (Kazancı Hukuk-Çevrimiçi-15.04.2021); Yargıtay 1 HD, 2015-15564, /2264, 25.02.2016 (Kazanc1 Hukuk-Çevrimiçi-15.04.2021); Yargıtay 1 HD, 2014-13563/561, 20.01.2016 (Kazancı Hukuk-Çevrimiçi-15.04.2021); Yargıtay 1 HD, 2014-9824/10454, 7.9 .2015 (Kazancı Hukuk-Çevrimiçi-15.04.2021); Yargıtay 1 HD, 2013-14562/312, 15.01.2014 (Kazancı Hukuk-Çevrimiçi-15.04.2021); Yargıtay 1 HD, 2585/6582, 5.6.2012 (Kazancı HukukÇevrimiçi-15.04.2021); Yargıtay 1 HD, 11277/10644, 20.10.2011 (Kazancı Hukuk-Çevrimiçi-15.04.2021); Yargıtay HGK, 1-61/107, 4.3.2009 (Kazancı Hukuk-Çevrimiçi-15.04.2021); Yargıtay HGK, 1-636/650, 22.10.2008 (Kazancı HukukÇevrimiçi-15.04.2021); Yargıtay 1 HD, 6629/8538, 7.7.2008 (Kazancı Hukuk-Çevrimiçi-15.04.2021);Yargıtay 1 HD, 12445/13020, 25.12.2006 (Kazancı Hukuk-Çevrimiçi-15.04.2021); Yargıtay 1 HD, 6540/6940, 8.6.2005 (Kazancı HukukÇevrimiçi-15.04.2021); Yargıtay 1 HD, 13977/14449, 27.12.2004 (Kazancı Hukuk-Çevrimiçi-15.04.2021); Yargıtay HGK, 1992-1-780/146, 7.4.1993 (Kazancı Hukuk-Çevrimiçi-15.04.2021). 
Muvazaa iddiasının söz konusu olduğu bir kararda ${ }^{76}$ bakım alacaklısı mirasbırakan önce 2008 yılında sonra 2009 yılında davalı ile ölünceye kadar bakma sözleşmesi yapmış ve söz konusu sözleşmelere istinaden bakım alacaklısı bakım borçlusuna taşınmazlarından bir kısmını devretmiştir. Davacılar ise muris muvazaası sebebiyle tapu iptali ve tescil, mümkün olmazsa tenkis isteğine ilişkin dava açmışlardır. Yargıtay vermiş olduğu kararda 2008 yılında yapılmış olan sözleşme ile bakım alacaklısının bakım ve gözetimini garanti altına aldığı için bu davanın reddi gerektiğine; 2009 yılında yapılan sözleşme ile devredilen taşınmazların değeri dikkate alındığında bakım alacaklısının daha önce oluşturduğu dengeyi bozarak mirasçılardan mal kaçırma amacıyla hareket ettiği için davanın bu kısmının ise kabul edilmesi gerektiğine karar vermiştir.

Bir diğer karara ${ }^{77}$ konu olan uyuşmazlıkta ise mirasbırakan yapmış olduğu bir ölünceye kadar bakma sözleşmesine istinaden malvarlığında yer alan en değerli taşınmazını bakım borçlusuna devretmiştir. Yargıtay bakım alacaklısının yaşlı olmasına rağmen bakıma muhtaç olmadığı ve kaldı ki bakım borçlusu tarafindan bakılmadığı, işlerini kendisi yaptığı, davalı kızının geçim masraflarını ve kirasını ödediği tespit edildiği için bakım alacaklısı mirasbırakanın asıl amacının davalı bakım borçlusuna bağış yapmak olduğu sonucuna varmış ve ölünceye kadar bakma sözleşmesinin muvazaa sebebiyle gizlenen bağışlama sözleşmesinin ise şekle aykırılık sebebiyle geçersiz olduğunu belirtmiştir. Başka bir ifade ile Yargıtay yalnızca bakım alacaklısının bağışlama yapma amacından yola çıkarak muvazaa sebebiyle sözleşmenin geçersiz olduğu sonucuna varılmıştır. Nitekim Yargıtay vermiş olduğu başka bir kararda da bakım alacaklısının eşi ve çocukları olmasına rağmen kendinden 26 yaş küçük bir kimseye ölünceye kadar bakma sözleşmesi kapsamında tek ve çok değerli olan malvarlığını devretmesinin mantıklı olmadığını ve bu sebeple söz konusu devrin mirasçılardan mal kaçırma amaçlı ve muvazaalı olduğu sonucuna varmıştı ${ }^{78}$.

Bakım alacaklısının mirasçılarından mal kaçırmak amacıyla ölünceye kadar bakma sözleşmesi kapsamında gerçekleştirdiği devirlere ilişkin yukarıda anılan kararlarda muvazaa iddiasının incelenmesi bakımından Yargıtay genellikle mirasçılardan mal kaçırma kastına ilişkin değerlendirmelerde bulunmuştur. Şöyle ki, anılan kararlarda bakım alacaklısının yaşı, fiziki durumu, aile ilişkileri, devretmiş olduğu malvarlığının değeri ve söz konusu malvarlığı değerinin bakım alacaklısının tüm malvarlığına oranı değerlendirildiğinde bakım alacaklısının mirasçılardan mal kaçırma saikiyle hareket ettiği tespit edilen devirlerde söz konusu devrin iptali gerektiği sonucuna varılmıştır. Kimi kararlarda da bakım alacaklısı mirasbırakanın özel bakım ihtiyacı, bakım borçlusunun eş olması hali, bakım alacaklısı ile bakım borçlusu arasındaki

76 Yargıtay 1 HD, 2016-15486/1151, 20.02.2020 (Kazancı Hukuk-Çevrimiçi-16.04.2021). Aynı yönde bkz.: Yargıtay 1 HD, 2016-17172/1556 4.3.2020 (Kazancı Hukuk-Çevrimiçi-16.04.2021).

77 Yargitay $1 \mathrm{HD}, 5085 / 7301,29.05 .1992$ (Akartepe (n 1) 297-298).

78 Yargitay 1 HD, 2008-9781/542, 20.01.2009 (Akartepe (n 1) 312-314). 
yaş farkı dikkate alınarak mirasbırakanın mirasçılardan mal kaçırma kastı ile hareket ettiğinden yola çıkılarak söz konusu işlemin muvazaalı olduğu belirtilmiştir. Başka bir ifade, söz konusu kararlarda muris muvazaasının varlığı bakımından yalnızca mirasbırakanın mirasçılardan mal kaçırma kastı değerlendirilerek sonuca varılmıştır. Oysaki bir devrin muris muvazaası ile bağlantılı olup olmadığı konusunda bir sonuca varılması bakımından söz konusu değerlendirme yeterli değildir.

Genel olarak, muvazaalı bir sözleşmede taraflar üçüncü kişileri aldatmak kastı ile görünüşteki irade beyanlarının hiçbir hukuki sonuç doğurmaması ya da görünüşteki irade beyanlarının arkasında gizlenen başka bir sözleşmenin hukuki sonuç doğurması yönünde anlaşmışlardır ${ }^{79}$. Muris muvazaasında ise muris, mirasçıları aldatmak ${ }^{80}$ ve onlardan mal kaçırmak amacıyla muvazaalı işlem yapmaktadır ${ }^{81}$. Başka bir ifade ile muris muvazaasında mirasbırakan mirasçılarını, miras haklarından yoksun bırakmak için muvazaalı bir işlemle malvarlığı devrinde bulunmaktadır ${ }^{82}$. Ancak görüldüğü üzere mirasbırakanın mirasçılarını miras hakkından yoksun bırakma ya da başka bir ifade ile mirasçılardan mal kaçırma kastı muris muvazaasının unsurlarından yalnızca biridir. Muris muvazaasından bahsedilebilmesi için öncelikli olarak görünüşte bir hukuki işlem olmalıdır. Görünüşteki hukuki işlemin amacı mirasçılar ya da üçüncü kişiler için farklı bir görünüş yaratarak esas yapmak istedikleri hukuki işlemi gizlemek ve bu sayede onların itirazlarını önlemektir ${ }^{83}$. Dolayısıyla muris muvazaasından bahsedilebilmesi için bir de görünüşteki hukuki işlemin altında gizlenen bir hukuki işlemin varlığı gerekmektedir. Söz konusu gizli hukuki işlem mirasbırakan ve mirasçı ya da üçüncü bir kişi arasında yapılan, tarafların ortak iradelerini içeren ve hüküm doğurmasını istedikleri hukuki işlemdir ${ }^{84}$. Bunlarla birlikte muris muvazaasından bahsedilebilmesinin başka bir şartı ise hukuki işlemin tarafları arasında muvazaalı işlem yapmak konusunda bir anlaşmanın (muvazaa anlaşması) varlığıdır ${ }^{85}$. Bu kapsamda mirasbırakan ve hukuki işlem yaptığı kimsenin görünüşteki hukuki işlemin kendi aralarında hüküm ifade etmeyeceği, buna mukabil

\footnotetext{
9 Necip Kocayusufpaşaoğlu, Borçlar Hukukuna Giriş Hukuki Işlem Sözleşme (4üncü Bası'dan 7inci Tıpkı Bası, Filiz 2017) $\S 35$ N. 1-4; von Tuhr (n 61) 273-274; Karayalçın (n 64 )53; Acabey (n 63) 473; Topuz (n 61) 711; Barış Demirsatan, "İrade Beyanlarının Yorumlanması Bakımından Muvazaa", (2020) 26 (2) Marmara Üniversitesi Hukuk Fakültesi Hukuk Araştırmaları Dergisi 1220, 1221-1222.

80 Aldatılan mirasçının temlik tarihinde mirasçı olup olmamasının bir öneminin olmadığı; temlik tarihinde mirasbırakanın aldatma amacı güttüğü bir mirasçısının olması ve iptal davası açıldığı tarihte de mirasçı sıfatını taşımasının yeterli olduğu yönünde bkz.: Yargıtay HGK, 4-359/405, 8.6.2011 (Kazanc1 Hukuk-Çevrimiçi-18.04.2021); Yılmaz (n 61) 114. Davacı mirasçının tapu iptali ve tescil davası açabilmesi için temlik tarihinde mirasçı olmasının şart olmadığı yönünde ayıca bkz.: Topuz (n 61) 716.

81 Acabey (n 63) 476; Y1lmaz (n 61) 109,113.

Muris muvazaasından bahsedilebilmesi için muvazaalı devrin mutlaka mirasçı ile yapılması gerekli değildir. Muvazaalı işlem mirasçı dışında üçüncü bir kişi ile de yapılmış olabilir. Bu yönde bkz.: Ayan (n 34) 239; Selin Sert Sütçü, Miras Bırakanın Muvazaalı Hukuki İşlemleri ve Sonuçları (2. Baskı, Seçkin 2019, s. 67; Yılmaz (n 61) 112. Yargıtay HGK, 1-458/498, 11.11.2009 (Kazancı Hukuk-Çevrimiçi-15.04.2021). Aksi yönde bkz.: Eren ve Yücer Aktürk (n 9) N. 876.

82 Yilmaz (n 61) 109.

83 Yilmaz (n 61) 112.

84 Yilmaz (n 61) 116.

85 Y1lmaz (n 61) 112.
} 
ortak iradelerini teşkil eden hukuki işlemin hüküm doğuracağı yönünde anlaşmaları halinde muvazaa anlaşmasının söz konusu olduğu sonucuna varılır ${ }^{86}$. Hukuki işlemin tarafları arasında böyle bir anlaşmanın olmaması halinde görünüşteki işlem gerçek işlem haline dönüşerek hukuki sonuçlarını doğurur ${ }^{87}$. Son olarak ise söz konusu muvazaalı işlemin mirasçıları aldatma kastı ile yapılmış olması gerekir ${ }^{88}$. Mirasçıları aldatma kast 1 ile hareket eden taraf mirasbirakandır ${ }^{89}$.

Bu bilgiler ışığında Yargıtay'ın ölünceye kadar bakma sözleşmesi kapsamında bakım alacaklısının mirasçılarından mal kaçırmak amacıyla yapmış olduğu muvazaalı devirlere ilişkin vermiş olduğu kararlar ele alındığında, yukarıda belirtilmiş olduğu üzere, yalnızca mirasbırakanın mirasçılardan mal kaçırma kastı göz önünde bulundurularak sonuca varıldığ 1 görülmektedir. Kanaatimizce, muris muvazaası iddiasının inceleme konusu yapıldığı durumlarda yalnızca mirasbırakanın mirasçılardan mal kaçırma unsuruna dayanılarak karara varılması isabetli bir yaklaşım değildir. Zira muris muvazaasından bahsedilebilmesi için başka unsurların da varlığı şarttır. Söz konusu değerlendirmelerdeki isabetsiz olan esas kısım muris muvazaası iddiası bakımından tarafların arasında bir muvazaa anlaşmasının mevcudiyetine ilişkin herhangi bir inceleme yapılmamış olmasıdır. Şöyle ki çalışmamız kapsamında incelenmiş olan kararlarda mirasbırakanın mirasçılardan mal kaçırma amacının tespit edilmesiyle birlikte doğrudan muris muvazaasının varlığ 1 kabul edilmektedir. Oysaki muvazaalı olduğu iddia edilen sözleşmenin tarafları arasında muvazaa anlaşması söz konusu değilse muris muvazaasından da bahsedilemeyecektir. Zira mirasbırakanın mirasçılardan mal kaçırma veya saklı pay kurallarını etkisiz kılma amacı tek başına her zaman bakım alacaklısı ve bakım borçlusu arasında bir muvazaa anlaşmasının varlığını ve ölünceye kadar bakma sözleşmesinin altında gizli bir bağışlama sözleşmesinin varlığını göstermez.

Muvazaalı bir ölünceye kadar bakma sözleşmesinin mevcut olabilmesi için ölünceye kadar bakma sözleşmesinin altında gizlenen, tarafların ortak iradelerini oluşturan bir bağışlama sözleşmesi olmalı ve tarafların kendi aralarında görünüşteki ölünceye kadar bakma sözleşmesinin değil bağışlama sözleşmesinin hüküm doğurması konusunda anlaşmış olmaları gerekir. Mirasçılardan mal kaçırma kastı veya saklı payı ihlal kastı ise yalnızca bakım alacaklısı mirasbırakanın iradesinde var olması gereken bir unsurdur; bakım borçlusunun bunu bilmesine dahi gerek yoktur. Bu sebeple mirasbırarakan saklı payı ihlal kastıyla veya mirasçılardan mal kaçırmak amacıyla bir ölünceye kadar bakma sözleşmesi yapmışsa bu sözleşmenin mutlaka

\footnotetext{
6 Yılmaz (n 61) 112. Ayrıca bkz.: Demirsatan (n 78) 1236-1237. Yazar, muvazaalı irade beyanın varlığı halinde, irade ve beyan arasında kasıtlı olarak bir farklılık yaratıldığı ve söz konusu irade beyanın hukuki sonuç doğurmasını engelleyen gerçek iradenin beyandan farklı olmasının muhatap tarafından bilinmesinin olduğunu belirtmektedir.

87 Kocayusufpaşaoğlu (n 78) § 35 N. 4.

88 Y1lmaz (n 61) 113. Ayrıca bkz.: Sert Sütçü (n 80) 67-68, 205.

89 Yilmaz (n 61) 113.
} 
muvazaa sebebiyle hükümsüz olduğu sonucuna varmak doğru olmayacaktır. Zaten ölünceye kadar bakma sözleşmesi kapsamında bakım borçlusu edimini gerçekten yerine getiriyorsa bakım alacaklısının mirasçılardan mal kaçırma ya da saklı payı etkisiz kılma kastı ile muvazaalı bir sözleşme yaptığı söylenemez. Zira bu noktada bakım alacaklısının gerçekten bakım ihtiyacını karşılamak için ölünceye kadar bakma sözleşmesini yaptığı sonucuna ulaşı1ır.

Bakım alacaklısı ile bakım borçlusu arasındaki ölünceye kadar bakma sözleşmesi karma bağışlama niteliğinde bir sözleşme ise bu noktada ölünceye kadar bakma sözleşmesinin yanında tarafların gerçek iradelerine uyan bir bağışlama sözleşmesi bulunmaktadır ${ }^{90}$. Söz konusu sözleşme tarafların gerçek iradesini yansıttığı için bu sözleşmenin muvazaa sebebiyle hükümsüz olduğunu söylemek oldukça güçtür. Ancak şartları varsa MK m. 565/I b.3 gereğince bu sözleşme kapsamında yapılan kazandırmaların tenkisi söz konusu olabilir. Öte yandan bakım alacaklısının mirasçılarından mal kaçırmak veya saklı pay kurallarını etkisiz kılmak kastı ile karma bağışlama niteliğinde ölünceye kadar bakma sözleşmesi yaptığı ihtimalde de doğrudan bu sözleşmenin muris muvazaası sebebiyle kesin hükümsüz olduğu kanısına varmak oldukça güçtür. Zira böyle bir sözleşmede bakım alacaklısı ile bakım borçlusu arasında gerçek iradelerine uygun olarak yapılmış olan karma bir bağışlama sözleşmesi vardır. Başka bir ifade ile bu durumda tarafların ortak iradeleri ölünceye kadar bakma sözleşmesi kisvesi altında esasen hüküm doğurması istenen bir gizli bağışlama sözleşmesi yapmak değil, gerçekten hüküm doğurmasını istedikleri karma bağışlama niteliğinde bir ölünceye kadar bakma sözleşmesi kurmaktır. Bu ihtimalde ise bakım alacaklısı mirasbırakanın saklı payı ihlal kastı ile söz konusu sözleşmeyi yaptığı ve bununla bağlantılı devirler gerçekleştirdiği ispatlanırsa bu sözleşme kapsamında yaptığı kazandırmaların MK m. 565/I b.4'e dayanarak tenkisi gündeme gelebilir. Ancak bakım alacaklısı mirasbırakan mirasçılardan mal kaçırmak amacıyla bakım borçlusu ile anlaşarak görünüşte bir ölünceye kadar bakma sözleşmesi yapmasına rağmen esasen gizli bir bağışlama sözleşmesi yapmış ve bu sözleşme hüküm doğurmuşsa bu durumda muris muvazaasından bahsedilecektir. Zira bu ihtimalde tarafların ortak olarak hüküm doğurmasını istedikleri gizli bağışlama sözleşmesi tarafların anlaşması ile bir ölünceye kadar bakma sözleşmesi altına saklanmıştır. Başka bir ifade ile tarafların ortak iradeleri ile hüküm doğurmasını istedikleri sözleşme görünüşteki ölünceye kadar bakma sözleşmesi değildir. $\mathrm{Bu}$ sebeple muvazaalı bir ölünceye kadar bakma sözleşmesini tespit edebilmek için yalnızca mirasbırakanın mirasçılardan mal kaçırma kastının varlığını tetkik etmek yeterli olmayacaktır; bakım borçlusu ve bakım alacaklısı arasında muvazaa anlaşmasının varlığını araştırmak gerekir.

90 Gizli bağışlama ve karma bağışlama kavramları için bkz.: Kocayusufpaşaoğlu (n 10) 396; Serozan, Baysal ve Sanlı (n 63) N. 995. 
Yapılan araştırmalar neticesinde muris muvazaası ile yapılmış olan ölünceye kadar bakma sözleşmesinin varlığının tespit edilmesi halinde bu sözleşme muvazaa sebebiyle hüküm doğurmayacaktır (BK m 19). Gizli bağışlama sözleşmesi ise esasen şekle tabi olması gerekirken somut olayda yasal şekil şartına uymadan yapıldığ 1 ihtimalde o da şekle aykırılıktan dolayı sonuç doğurmayacaktır. Bu ihtimalde sözleşmenin konusu bir taşınmaz ise tapu iptal ve tescil davası açılarak taşınmazın terekeye iadesi sağlanabilir ${ }^{91}$. Ancak gizli bağışlama sözleşmesinin geçersizliğini gerektiren bir sebep mevcut değilse bu sözleşme hüküm doğuracaktır ve şartları varsa MK m. 565/I uyarınca tenkisi gündeme gelebilir.

\section{Sonuç}

MK m. 565'te yer alan tenkise tabi olan sağlararası kazandırmaların ortak özelliği karşılıksız kazandırma olmalarıdır. Çalışmamızın konusunu teşkil eden ölünceye kadar bakma sözleşmesi ise tam iki tarafa borç yükleyen ivazlı bir sözleşmedir. Bu kapsamda bakım borçlusunun yerine getirmesi gereken temel yükümlülüğü bakım alacaklısına ölünceye kadar bakıp onu gözetmektir. Miras hukukuna tabi bir ölünceye kadar bakma sözleşmesinin varlığ halinde bakım alacaklısı bakım borçlusunu mirasçı atayarak ya da vasiyet alacaklısı tayin ederek karşı edimini yerine getirmiş olacaktır. Çalışmamızda ele alınan borçlar hukukuna tabi bir ölünceye kadar bakma sözleşmesinin varlığ değeri devretmekle yükümlüdür ve söz konusu devri gerçekleştirerek karşı edimini ifa etmiş olacaktır. Bu bilgiler ışığında ölünceye kadar bakma sözleşmesinin ivazlı bir sözleşme olması sebebiyle tenkise tabi olmayacağı sonucuna varılabilir.

Kimi durumlarda ölünceye kadar bakma sözleşmesi bağışlama sözleşmesi ile bir arada bulunabilir; başka bir ifade ile karma bağışlama teşkil edebilir. Bu durumda karma bağışlama niteliğindeki ölünceye kadar bakma sözleşmesinin yalnızca karşılıksız olan kısmı tenkise tabi olacaktır.

Karma bağışlama niteliğini haiz olan bir ölünceye kadar bakma sözleşmesi kapsamında yapılmış olan sağlararası bir kazandırmanın, çalışmamızın konusu olan MK m. 565/I b. 4 uyarınca tenkise tabi olabilmesi için söz konusu kazandırmanın bakım alacaklısı tarafindan saklı pay kurallarını etkisiz kılmak kastı ile yapılmış olması gerekir. Ancak öncelikle belirtilmelidir ki mirasbırakanın karma bağışlamada bulunması mutlaka onun saklı pay kurallarını etkisiz kılma kastı ile hareket ettiği

\footnotetext{
Yargıtay'ın 22.05.1987 tarihinde vermiş olduğu içtihadı birleştirme kararı uyarınca ise, mirasbırakanın yaptığı temliki tasarruflardan zarar gören mirasçıların tenkis davası ile birlikte kademeli olarak veya tenkis davası açtıktan sonra ayrı bir dilekçe ile muvazaa nedeniyle iptal-tescil davası açabileceklerinin sonucuna varılmıştır. Bu yönde bkz.: Yargıtay İBGK 1986-4/5, 22.05.1987 (Kazancı Hukuk-Çevrimiçi-17.04.2021). Ancak doktrinde bir görüş, davacı ister muvazaa sebebiyle hükümsüzlük isterse de tenkis davası açmış olsun görünüşteki işlemin muvazaa sebebiyle incelenmesi gerektiği; söz konusu sözleşmenin muvazaa sebebiyle geçersiz olduğu ihtimalde onun arkasındaki gizli bağışlama sözleşmesinin şekil noksanlığı söz konusu ise tapu kütüğünün düzeltilmesinin; gizli bağışlamaya karşı herhangi bir geçersizlik sebebi ileri sürülemiyorsa bunun tenkisinin talep edilmesi gerektiğini belirtmiştir. Bu görüş için bkz.: Kocayusufpaşaoğlu (n 64) s. 26.
} 
anlamına gelmemektedir ${ }^{92}$. Bakım alacaklısı karma bağ kadar bakma sözleşmesi yapmasına rağmen saklı pay kurallarını etkisiz kılmak amacıyla hareket etmiyorsa bu durumda söz konusu sözleşmeye dayanılarak yapılan kazandırma MK m. 565/I b. 4'e göre değil, şartları sağladığı takdirde MK m. 565/I b. 3 uyarınca tenkis edilebilir. Ancak bakım alacaklısı yapacağı devirle saklı paylı mirasçılarının haklarını ihlal edebileceğini öngörmesine rağmen yine de söz konusu devri gerçekleştirdiği durumda bakım borçlusu lehine yapılan kazandırma MK m. 565/I b. 4'e göre tenkis edilebilir. Bakım alacaklısının saklı payı ihlal kastının bakım borçlusu tarafından bilinmesi ya da bakım borçlusu ile yapılmış olan sözleşmede bu konu üzerinde anlaşılmış olmasına gerek yoktur.

Ölünceye kadar bakma sözleşmesinin MK m. 565/I b. 4 uyarınca tenkisine ilişkin Yargıtay tarafından verilmiş olan kararlarda belirli ölçütler kullanılarak bakım alacaklısının saklı payı ihlal kastı tartışılmıştır. Söz konusu ölçütlerden birisi bakım alacaklısının özel bakım ihtiyacıdır. Yargıtay'ın vermiş olduğu kararlarda bakım alacaklısının özel bakım ihtiyacı içerisinde olmamasının saklı payı ihlal kastına işaret edip etmediği tartışılmıştır. Yargıtay tarafından verilmiş olan bazı kararlarda da belirtilmiş olduğu üzere ölünceye kadar bakma sözleşmesinin kurulması aşamasında bakım alacaklısının özel bakım ihtiyacı içerisinde olmasını aramak yasal olarak belirtilmemiş olan yeni bir şart öngörmektir. Bu sebeple bakım alacaklısı özel bakım ihtiyacı içerisinde olmadığı bir zaman ölünceye kadar bakma sözleşmesi yapmış olsa bile bu durum onun saklı payı ihlal kastı ile hareket ettiğini göstermez.

Yargı kararlarında ayrıca bakım alacaklısının ve borçlusunun edimleri arasında dengesizlik varsa veya bakım alacaklısı malvarlı̆̆ının tamamı ya da büyük bir kısmını bakım borçlusuna devretmişse saklı payı ihlal kastı ile hareket etmiş olabileceği sonucuna varmıştır. Kanaatimizce, bakım alacaklısıyla bakım borçlusunun edimleri arasında oransızlık olsa bile bu durum doğrudan bakım alacaklısının saklı payı ihlal kastı ile hareket ettiği sonucunu doğurmaz. Edimler arası dengesizlik taraflar arasında karma bağışlamanın var olabileceğini gösterse de saklı payı ihlal kastından bahsedilebilmesi için tek başına yeterli değildir. Ancak somut olayda bu hususun başka unsurlarla da desteklenmesi halinde saklı payı ihlal kastının varlığından söz edilebilir. Örneğin, bakım alacaklısı ile bakım borçlusun edimleri arasındaki dengesizlik çok ciddi boyuttaysa ve bakım alacaklısının saklı paylı mirasçılarına öldükten sonra miras olarak herhangi bir şey bırakmak istemediği hususu tanık beyanı ya da başka şekilde de desteklenebiliyorsa bu durumda o sözleşmeye dayanılarak yapılmış olan kazandırma MK m. 565/I b. 4 uyarınca tenkis edilebilir. Aynı durum bakım alacaklısının bakım borçlusuna karşı edim olarak malvarlığının tamamını ya da büyük bir kısmını devretmiş olduğu durumlar bakımından da geçerlidir. Bakım alacaklısının malvarlığında tek bir malvarlığı değeri bulunuyorsa ya da malvarlığının 
büyük bir kısmı bakım borçlusunun karşı edimini teşkil edecek nitelikte ise bakım alacaklısının sırf bu nedenle saklı payı ihlal kastı ile hareket ettiğinden bahsedilemez. Söz konusu hususun başka türlü delillerle desteklenmesi gerekir.

Bakım alacaklısı mirasbırakan bazen de saklı pay kurallarını ihlal kastı ile hareket etmesine rağmen yapmış olduğu kazandırmanın ileride tenkis edilmesini önlemek için muvazaalı işlemlere başvurabilir. Bu ihtimalde söz konusu kazandırmaların tenkis edilmesi mümkün değildir; zira bir kazandırmanın tenkis edilebilmesi için o kazandırmanın geçerli bir kazandırma olması gerekir. Dolayısıyla bakım alacaklısı mirasbırakan saklı payı ihlal veya mirasçılardan mal kaçırma kastı ile muvazaalı bir işlem yapıyorsa söz konusu kazandırmanın iptali talep edilerek terekeye iadesi sağlanmalıdır. Bu noktada söz konusu kazandırmanın muvazaa sebebiyle iptali ve bu mümkün değilse tenkisi terditli olarak talep edilebilir. Muvazaalı olduğu iddia edilen ölünceye kadar bakma sözleşmesinin muris muvazaası sebebiyle hükümsüz kabul edilebilmesi mirasçılardan mal kaçırma kastı ile yapılması yeterli değildir. Yukarıda anıldığı üzere bu konuyla alakalı Yargıtay kararlarında değerlendirilen husus çoğunlukla mirasçılardan mal kaçırma kastına ilişkindir. Ölünceye kadar bakma sözleşmesinin muvazaa sebebiyle hükümsüz olduğu sonucuna varılabilmesi için bu sözleşmenin esasen bir bağışlama sözleşmesini gizlemek amacıyla yapıldı̆̆ı, tarafların ortak iradelerinin kendi aralarında bağışlama sözleşmesinin hüküm doğurmas1 yönünde olduğu ve dolayısıyla aralarında muvazaa anlaşmasının mevcudiyeti tespit edilmelidir. Dolayısıyla yalnızca bakım alacaklısı mirasbırakanın mirasçılardan mal kaçırma kastının incelenerek muvazaa iddiasının değerlendirilmesi isabetli değildir.

\footnotetext{
Hakem Değerlendirmesi: Dış bağımsız.

Çıkar Çatışması: Yazar çıkar çatışması bildirmemiştir.

Finansal Destek: Yazar bu çalışma için finansal destek almadığını beyan etmiştir.

Peer-review: Externally peer-reviewed.

Conflict of Interest: The author has no conflict of interest to declare.

Grant Support: The author declared that this study has received no financial support.
} 


\section{Bibliyografya/Bibliography}

Acabey B, "Yargıtay Kararları Işı̆̆ında Muris Muvazaası", Tuğçe Tuzcuoğlu ve A. Hulki Cihan (eds), Yargıtay Kararları Işı̆̆ııda Güncel Medeni Hukuk Problemleri Sempozyumu Bildirileri 8-9 Kasim 2018 (On İki Levha 2019) 471-487.

Akartepe A, Ölünceye Kadar Bakma Sözleşmesi, (Vedat 2010).

Akbıyık C, Karma Bağışlama Kavramı ve Miras Hukukundaki Yeri (Alfa 1997).

Akipek Öcal Ş, “Ölünceye Kadar Bakma Sözleşmesi”, (2018) 6(1) Kadir Has Üniversitesi Hukuk Fakültesi Dergisi 83-91.

Akkök S, Türk Hukuku'nda Miras Bırakanın Muvazaalı Işslemleri ve Buna Bağlanan Hukuki Sonuçlar, (On İki Levha, 2020).

Antalya G ve Sağlam İ, Miras Hukuku (4. Bask1, Seçkin 2019).

Arık F, “Ölünceye Kadar Bakma Akdi”, (1959) 3 Adliye Dergisi 277-377.

Ayan M, Miras Hukuku, (10. Bask1, Adalet 2020).

Aydın Ünver T, “Miras Bırakanın Yasa Gereği Denkleştirmeye Tabi Olan Kazandırmaları”, Prof. Dr. Şener Akyol'a Armağan, (Filiz 2011) 111-146.

Bauer T, Basler Kommentar Obligationenrecht I Art. 1-529, Herausgeber: Heinrich Honsel1/ Nedim Peter Vogt/ Wolfgang Wiegand, (6. Auflage, Helbing Lichtenhahn 2015).

Bilge N, Borçlar Hukuku Özel Borç Münasebetleri (Banka ve Ticaret Hukuku Enstitüsü, 1971).

Brigitta K, Präjudizienbuch OR Die Rechtsprechung des Bundesgerichts (1875-2015) (Schulthess Verlag, 2016).

Bucher E, Schweizerisches Obligationenrecht Besonderer Teil, (3. Auflage, Schulthess 1988).

Çabri S, Miras Hukuku Şerhi (TMK m. 495-574) Cilt-I (On İki Levha, 2018).

Dalamanlı L, Tatbikatta Satış Vaadleri Ölünceye Kadar Bakma ve Miras Taksim Sözleşmeleri (Kazanc1 1980).

Demirsatan B “İrade Beyanlarının Yorumlanması Bakımından Muvazaa”, (2020) 26 (2) Marmara Üniversitesi Hukuk Fakültesi Hukuk Araştırmaları Dergisi 1220-1241.

Durak Y, “Ölünceye Kadar Bakma Sözleşmesi”, 2015 1(1) Başkent Üniversitesi Hukuku Fakültesi Dergisi 265-299.

Dural M ve Öz T, Türk Özel Hukuku Cilt IV Miras Hukuku (Filiz 2019).

Eren F, Türk Medeni Hukukunda Tenkis Davası (Sevinç 1973).

Eren F, Borçlar Hukuku Özel Hükümler (8. Bask1, Yetkin 2020).

Eren F ve Yücer Aktürk İ, Türk Miras Hukuku, (3. Bask1, Yetkin 2020).

Eviz E, Muris Muvazaası (On İki Levha, 2019).

Frédéric K, Präjudizienbuch OR Die Rechtsprechung des Bundesgerichts (1875-2015), Herausgeber: Peter Gauch/Viktor Aepli/Hubert Stöckli (Neunte Auflage, Schulthess, 2016).

Günay E, Ölünceye Kadar Bakıp Gözetme Sözleşmesinden Kaynaklanan Uyuşmazlıklar (3. Bask1, Seçkin 2020).

İmre Z ve Erman H, Miras Hukuku (15. Basım, Der 2021).

İnan AN, Ertaş Ş ve Albaş H, Miras Hukuku (10. Bası, Seçkin 2019).

Karayalçın Y, Mirasbırakanın Muvazaası mı? Tasarruf Özgürlüğ̈̈ ve Saklı Payın Korunması mı? (Turhan 2000).

Kocayusufpaşaoğlu N, Miras Hukuku (3. Bas1, Filiz 1987). 
Kocayusufpaşaoğlu N, Borçlar Hukukuna Girişs Hukuki İşlem Sözleşme, (4üncü Bası'dan 7inci Tipk1 Bas1, Filiz 2017).

Kocayusufpaşaoğlu N, Miras Hukuku 2. ve 3. Basılara Ek Kitap, (Filiz 1992).

Köprülü B, Miras Hukuku Dersleri, (2. Bas1, Fakülteler 1985).

Marco B, CHK - Handkommentar zum Schweizer Privatrecht Vertragsverhältnisse Teil 2: Arbeitsvertrag, Werkvertrag, Auftrag, GoA, Bürgschaft Art. 319-529 OR 3. Auflage, Schulthess 2016).

Mardin E, Ölünceye Kadar Bakma Mukavelesi, (Hukuk Fakültesi Mecmuasından Ayrı Bası, Kenan 1940).

Nar A, Türk Miras Hukukunda Tenkis, (On İki Levha 2016).

Oğuzman, MK, Miras Hukuku, (5. Bas1, Filiz 1991).

Olgaç S, Ömür Boyunca Gelir Ölünceye Kadar Bakma Akdi (Olgaç 1978).

Öztan B, Miras Hukuku (11. Bas1, Yetkin 2020).

Özuğur Aİ, Tenkis, Mirasta Denkleştirme ve Muvazaa Davaları, (5. Bask1, Adalet 2015).

Piotet P, Schweizeriches Privatrecht, Vierter Band, Erbrecht, (Helbing \& Lichtenhahn 1978).

Roland F, CHK - Handkommentar zum Schweizer Privatrecht, Erbrecht, Art. 457-640 ZGB (3. Auflage, Schulthess 2016).

Schaetzle M, Berner Kommentar, Das Obligationenrecht, 2. Abteilung Die einzelnen Vertragsverhceltnisse, 7. Teilband, (Zweite Auflage, Verlag Stampfli 1978) (Artikel 516-529 OR).

Serozan R ve Engin Bİ, Miras Hukuku (6. Bask1, Seçkin, 2019).

Serozan R, Baysal B ve Sanlı KC, Borçlar Hukuku Özel Bölüm, (3. Bası, On İki Levha 2018).

Sert Sütçü S, Miras Bırakanın Muvazaalı Hukuki İşlemleri ve Sonuçları, (2. Baskı, Seçkin 2019).

Şahin T, Ölünceye Kadar Bakma Sözleşmesi, (Seçkin 2019).

Tekdoğan A, "Sağlararası Tasarrufların Tenkisi”, (2017) 12 (133) Terazi Hukuk Dergisi 86-100.

Topuz M, "Yargıtay Kararları Işı̆̆ında Muris Muvazaasının Varlığını Gösteren Emareler" (2016) 15(2) İstanbul Kültür Üniversitesi Hukuk Fakültesi Dergisi (Prof. Dr. M. İlhan Ulusan'a Armağan, Cilt II) 709-727.

Tunçomağ K, Ölünceye Kadar Bakma Akdi (Ayyıldız 1959).

Turanboy KN, Mirasbırakanın Denkleștirme ve Tenkise Bağlı Sağlararası Hukuki Işslemleri (Yetkin 2010).

Tüfek KG, Miras Hukukunda Tenkis ve İade Davaları (Olgaç 1977).

Vardar Hamamcıŏlu G, Taşınır ve Taşınmaz Mülkiyetini Konu Alan Bağışlama Sözleşmesi (2. Bask1, Adalet 2020).

Von Tuhr A, Borçlar Hukukunun Umumi Kısmı Cilt:1-2, Cevat Edege (Çev.), (Yargıtay 1983).

Wolf S, "Verfügungen unter Lebenden vs. «unzulässige» Umgehung der Verfügungsbeschränkung - wann greift die Herabsetzungsklage gemäss Art. 527 Ziff. 4 ZGB? ”2014 (150 ) Zeitschrift des bernischen Juristenvereins 435-459.

Yannick M, Orell Füssli Kommentar ZGB Kommentar Schweizerisches Zivilgesetzbuch (3. Auflage, Orell Füssli 2016).

Y1lmaz S, Muris Muvazaası (Yetkin 2021).

Zevkliler A ve Gökyayla KE, Borçlar Hukuku Özel Borç İlişkileri (20. Bası, Vedat 2020). 
